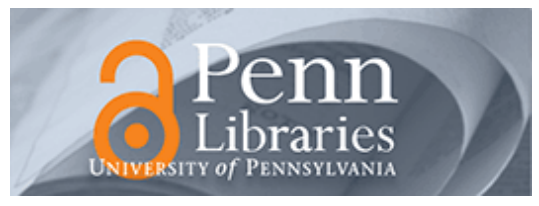

University of Pennsylvania

ScholarlyCommons

Management Papers

Wharton Faculty Research

$1-2008$

\title{
The Fit Between Product Market Strategy and Business Model: Implications for Firm Performance
}

Christopher Zott

Raphael H. Amit

University of Pennsylvania

Follow this and additional works at: https://repository.upenn.edu/mgmt_papers

Part of the Business Administration, Management, and Operations Commons

Recommended Citation

Zott, C., \& Amit, R. H. (2008). The Fit Between Product Market Strategy and Business Model: Implications for Firm Performance. Strategic Management Journal, 29 (1), 1-26. http://dx.doi.org/10.1002/smj.642

This paper is posted at ScholarlyCommons. https://repository.upenn.edu/mgmt_papers/48

For more information, please contact repository@pobox.upenn.edu. 


\title{
The Fit Between Product Market Strategy and Business Model: Implications for Firm Performance
}

\begin{abstract}
We examine the fit between a firm's product market strategy and its business model. We develop a formal model in order to analyze the contingent effects of product market strategy and business model choices on firm performance. We investigate a unique, manually collected dataset, and find that novelty-centered business models-coupled with product market strategies that emphasize differentiation, cost leadership, or early market entry-can enhance firm performance. Our data suggest that business model and product market strategy are complements, not substitutes.
\end{abstract}

\section{Keywords}

product market strategy, business model, performance, contingency theory, competitive strategy

Disciplines

Business Administration, Management, and Operations 


\title{
Exploring the Fit Between Business Strategy and Business Model: Implications for Firm Performance*
}

\author{
Christoph Zott \\ INSEAD \\ Euro-Asia Center 006 \\ Boulevard de Constance \\ 77305 Fontainebleau Cedex \\ FRANCE \\ Telephone: 33160724364 \\ Fax: 33160724223 \\ E-mail: christoph.zott@insead.edu \\ Raphael Amit \\ The Wharton School \\ University of Pennsylvania \\ 3620 Locust Walk \\ Philadelphia, PA 19104-6370 \\ Telephone: (215) 898-7731 \\ Fax: (215) 573-7189 \\ E-mail: amit@wharton.upenn.edu
}

15 May 2006

\footnotetext{
* Both authors contributed equally to this article. We gratefully acknowledge the financial support of the Wharton-INSEAD Alliance Center for Global Research \& Development. Christoph Zott acknowledges support from the Rudolf and Valeria Maag Fellowship in Entrepreneurship at INSEAD. Raffi Amit acknowledges financial support from the Wharton e-Business Initiative (a unit of the Mack Center) and the Robert B. Goergen Chair in Entrepreneurship at the Wharton School. We thank Iwona Bancerek, Amee Kamdar, Jenny Koelle and Gueram Sargsyan for valuable research assistance.
} 


\title{
Exploring the Fit Between Business Strategy and Business Model: Implications for Firm Performance
}

\begin{abstract}
In this paper, we explore the fit between a firm's product market strategy, and its business model. We develop a formal model in order to analyze and develop theoretical hypotheses on the contingent effects of product market strategy and business model choices on firm performance. By investigating a unique, manually collected data set, we find that novelty-centered business models, coupled with product market strategies that emphasize differentiation, cost leadership, or early market entry, enhance firm performance.
\end{abstract}

KEYWORDS: Product market strategy, business model, performance, contingency theory, competitive strategy. 


\section{Exploring the Fit Between Business Strategy and Business Model: Implications for Firm Performance}

A central objective of strategic management research has been to understand the contingent effects of strategy on firm performance. Contingency theory suggests that there is no optimal strategy for all organizations and posits that the most desirable choice of strategy varies according to certain factors, which are termed contingency factors (Donaldson, 1996). Accordingly, strategic management scholars have examined a wide range of contingency factors, such as aspects of the environment, organization structure (Miller, 1988), technology (Dowling and McGee, 1994), and marketing choices (Claycomb, Germain and Droege, 2000), amongst other things, and explored how these factors interact with strategy variables to determine firm performance.

One focus of that literature considers structural forms as contingency factors. An important early contribution to that literature was made by Chandler (1962) who considered the contingency relationship between a firm's strategy and its internal administrative structure (specifically, divisional versus functional form). While this particular pair of strategy/structure variables has been thoroughly addressed (e.g., see Amburgey and Dacin, 1994), the received literature seems to have paid surprisingly "little attention to extending the question of strategy/structure fit issues for other structural forms of organization" (Yin and Zajac, 2004: 365). In this paper, we address this gap in the literature on the contingent effects of strategy on firm performance by introducing the firm's business model as a new contingency factor that captures the structure of firm's boundary-spanning exchanges. We ask the following research question: How do the firm's business model and its product market positioning strategy interact to impact firm performance?

We address this question by elaborating on the business model, which is a relatively new, yet rich, and potentially powerful concept in the strategy literature. The business model is a structural template of how a focal firm transacts with all its external constituents, whether they are customers or other parties. In other words, it describes how the firm connects with factor and product markets. This is a 
fundamental choice that a firm has to make in deciding how to compete. Another fundamental choice that managers have to make when deciding how to compete is what product market strategy to adopt. This paper attempts to shed light on how these choices fit with each other.

The business model has been brought to the forefront of strategic management thinking, and it has become a particularly important new contingency factor through recent rapid advances in information and communication technologies - in particular, Internet and broadband technologies - that have facilitated new types of technology-mediated interactions between economic agents (Geoffrion and Krishnan, 2003). These developments have enabled firms to change fundamentally the way they organize and transact both within and across firm and industry boundaries (Mendelson, 2000), and they have given rise to an emerging approach to enterprise-level design as Nadler and Tushman (1997: 120) have asserted: That approach spawns "new designs that extend beyond the corporation's traditional outer walls," and it helps managers "recognize the untapped opportunities for competitive advantage that lie within their own organizations." Thus, the focus of organization design seems to have shifted from the administrative structure of the firm to the structural organization of its exchanges with external stakeholders. Echoing this shift, researchers have observed that the locus of value creation increasingly extends traditional firm boundaries (Dyer and Singh, 1998; Gulati, Nohira and Zaheer, 2000; Normann, 2001), and they have therefore called for a broader conceptualization of organizational boundaries beyond the legally relevant demarcation of the firm from its environment (Santos and Eisenhardt, 2005). The business model represents such a broader concept.

The study of business models is an important topic for strategic management research because business models affect firms' possibilities for value creation and value capture (Amit and Zott, 2001). Since strategies are also chosen, or emerge, in order to increase value creation and capture by firms, researchers and managers need to understand how business models and strategy, both independently as well as jointly, impact the performance prospects of firms. In other words, the business model needs to be taken into account as an important new contingency factor to affect the strategy-performance relationship. In order to improve our understanding of the contingent effects of business model and strategy, we first 
examine in this paper conceptually how a firm's business model is distinct from its product-market strategy, and we then investigate theoretically how various product market strategies and business model choices interact to affect firm performance. Thereby, we extend the theory on the contingent effects of strategy on performance, and more specifically on the fit between strategy and structure.

By examining a unique hand-collected data set on business strategy and business models, we establish empirically that a firm's product market strategy and its business model are distinct constructs that affect firm performance. Specifically, we find that novelty-centered business models, coupled either with a differentiation or cost leadership strategy, enhance firm performance. In addition, we ascertain that a novelty-centered business model joined with early entry into a market positively affects performance.

This study makes the following contributions to the strategy literature: First, it extends the scholarly perspective of structure as an important contingency factor, from being concerned with the administrative structure of the firm to a focus on the pattern of transactions the focal firm enables with external stakeholders. Second, in this paper we argue theoretically, and show empirically that the business model is a valid construct and distinct from received notions of a firm's product market strategy. This is the first paper to empirically establish the discriminant validity of the business model construct. Third, we articulate formally how interactions among the main constructs are expected to affect firm performance. In other words, we derive analytically the contingent effects of business model and strategy on firm performance. This, too, to the best of our knowledge, has not been done before. Fourth, we test these theoretical developments empirically, and show that novel business models can augment the competitive advantage realized through superior product market strategies. In other words, we show that both product market strategy and structure as embodied by the business model can enhance the firm's competitive advantage, independently as well as jointly.

The remainder of the paper is organized as follows: We proceed in the next section to present our theory, after which we explain the data and methods we used to test it. We then present our results, and we conclude with a discussion of our findings and implications for future research. 


\section{THEORY}

\section{Contingency Relationship of Strategy and Structure}

Contingency theory seeks to understand the behavior of a firm by separately analyzing its constituent parts, making disaggregated one-to-one comparisons of variables and their links with performance (Meyer, Tsui and Hinings, 1993). A prominent concern among contingency theorists has been to explore variables related to the strategy and structure of firms (e.g., Doty, Glick and Huber, 1993; Galbraith, 1977; Miles and Snow, 1978; Mintzberg, 1979), and to examine their contingent effects on firm performance. For example, in his study of large American corporations and their approaches toward product-market diversification, Alfred Chandler (1962) observed that major increases in volume, geographic dispersion, and vertical and horizontal integration of firms were followed by changes in their administrative activity, which eventually led to the emergence of the M-form of organization. That line of reasoning, however, provoked the counterargument that "strategy follows structure" (e.g., Bower, 1970), which was predicated on the logic that managerial cognition and skills mediate between structure and strategy. The ensuing debate in the strategy literature on the contingent relationship between strategy, structure, and firm performance, flourished in the 1970s and 1980s, and has subsequently been revived through a closer empirical examination of dynamics and causality (Amburgey and Dacin, 1994) as well as calls for an extension of the analysis to various forms of strategy and structure that had previously not been considered (e.g., Nadler and Tushman, 1997; Yin and Zajac, 2004).

In this paper, we attempt to enrich the debate on the strategy/structure fit by shifting the focus from corporate to business level strategy, and by focusing on a structural construct that captures the firm's transactions with external parties, namely, the firm's business model. Specifically, with respect to the former, we concentrate on some salient aspects of a firm's product market strategy. We view product market strategy as the way in which a firm chooses to build, exploit, and safeguard advantages in its addressable market spaces by making the following main decisions: (1) What type of product market positioning approach to adopt (i.e., cost leadership and/or product/service differentiation; see Porter, 1985); and (2) When to enter the market (Lieberman and Montgomery, 1988). The answers to these 
questions are central to our understanding of how firms that operate in competitive product markets create and appropriate value.

\section{Business Model: A New Structural Concept}

Technological progress has brought about new opportunities for the creation of organizational arrangements among firms, partners, and customers (Geoffrion and Krishnan, 2003; Mendelson, 2000; Normann, 2001), i.e. for the creation of new business models. The business model is a structural template of how a focal firm interacts and transacts with customers, partners, and vendors, that is, how it chooses to connect with factor and product markets. It refers to the overall gestalt of these possibly interlinked transactions. Consider the case of Priceline.com Inc., a provider of an electronic pricing system, known as demand collection system (Hann and Terwiesch, 2003). Transactions are enabled through a reverse market auction mechanism for which the company has secured a business method patent. It allows the customer to name the price at which they wish to transact and the company will attempt to find a provider of the product or service within a specified range. That business model enables buyers to save money on a wide range of products and services by trading flexibility regarding the choice of brands, product features, timing, convenience and/or sellers in return for prices that are lower than those charged through traditional retail channels. Further, Priceline enables sellers to generate incremental revenue by disposing of excess inventory or capacity at prices that are lower than the ones they offer through other channels while protecting their brand.

The business model can then be defined as "the structure, content, and governance of transactions" between the focal firm and its exchange partners (Amit and Zott, 2001:511). ${ }^{1}$ It represents a

\footnotetext{
${ }^{1}$ There are other definitions of the term business model, for example, those that define it as the way a firm generates revenues (for an overview, see Ghaziani and Ventresca, 2005). For the purpose of this article, however, we rely on the definition proposed by Amit and Zott (2001), and on their distinction between business and revenue model: a revenue model refers to the specific modes in which a business model enables revenue generation. We view the business model as a logical prior to the revenue model. It
} 
conceptualization of the pattern of transactional links between the firm and its exchange partners. ${ }^{2}$ Business models can be characterized by their design themes, which capture the common threads that orchestrate and connect the focal firm's transactions with external parties. In this paper we focus on "novelty-centered" and "efficiency-centered" business models (Zott and Amit, 2003), because they are the corresponding themes (on the business model level) to product differentiation and cost leadership, as well as early and late market entry (on the business strategy level), and thus are the most appropriate contingency factors to consider. This choice of design themes therefore suits our theoretical purpose of exploring the fit between business model and business strategy.

Novelty-centered business models refer to new ways of conducting economic exchanges among various participants. The conceptualization and adoption of new ways of conducting transactions can be achieved, for example, by connecting previously unconnected parties, by linking transaction participants in new ways, or by designing new transaction mechanisms (see the example of Priceline). Efficiencycentered business models refer to the measures firms may take with the intention to achieve transaction efficiency (i.e., reduce transaction costs for all participants); they do not refer to the outcome (i.e., efficiency) itself. The essence of an efficiency-centered business model is thus the reduction of transaction costs (Williamson, 1975). This reduction can derive from the attenuation of uncertainty, complexity, or information asymmetry, as well as from reduced coordination costs and transaction risk. An example of efficiency-centered design would be the order-tracking feature in Amazon's business model, which is aimed at enhancing transaction transparency, and thus at increasing efficiency.

is the relevant construct for understanding how value is created, and thus is a prerequisite for understanding how value is appropriated, which is then captured by the revenue model construct.

${ }^{2}$ We note that the business model construct is distinct from the value net strategic analysis framework developed by Brandenburger and Nalebuff (1996). The players in the value net such as competitors and certain complementors may or may not be part of the business model because some of these players may not transact with the focal firm. 
These design themes - novelty and efficiency - are neither orthogonal (for instance, novel design may engender lower transaction costs), nor are they mutually exclusive: Both may be present in any given business model. Moreover, the design themes are not exhaustive as there may be other themes present in a business model. The design themes describe the holistic gestalt of a firm's business model, and they facilitate its conceptualization and measurement.

The business model can be a source of competitive advantage that is distinct from the firm's market position (Christensen, 2001). Firms that address the same customer need, and that pursue similar product market strategies, can nonetheless do so with very different business models. Consider, for example, the market for navigation software for handheld devices such as personal digital assistants, handheld computers, or smart phones. Some firms in that space offer non-wireless solutions directly to the end-user in a one-shot transaction, while others like the French company Webraska offer wireless navigation solutions that can be sold through the wireless carriers, and that require a very distinct set of on-going exchanges between the firm, end-users, and the wireless carriers (Zott and Bancerek, 2004). A firm with a distinct business model that creates more value than that of its rivals holds a potential advantage over its rivals as it has the possibility to capture more value for its shareholders, all other things being equal. Consequently, a business model affects firm performance outcomes, as does a firm's product market strategy, and therefore its contingent effects on strategy need to be considered. In Table 1 we contrast business model and product market strategy.

\section{[INSERT TABLE 1 HERE]}

Table 1 illustrates that product market strategy differs from the business model mainly through its focus on the positioning of the firm vis-à-vis rivals, whereas the business model centers more on the pattern of the firm's economic exchanges with external parties in its addressable factor and product markets. Referring to the Priceline example, we note that although the product-market strategy of Priceline is cost leadership, its business model centers on novelty. This leads us to propose a corollary, which we state explicitly because the conceptual arguments that support the conjecture that business 
models and business strategy differ are relatively new (e.g., see Magretta, 2002), and may not yet be widely known or accepted. They have also not yet been empirically established.

Corollary: Business models (as, for example, measured by design themes) are distinct from product market strategies (as, for example, measured by generic strategies).

Based on the proposed distinction between the business model and product market strategy constructs, we proceed to examine the fit between them, and the implications thereof. Contingency theory implies that organizational effectiveness (for example, measured in terms of firm performance) is a function of the fit between contingency factors. According to Galbraith (1977:6) fit or "coherence is the primary determinant of success." For example, alignment between a firm's administrative structure and its diversification strategy is argued to have positive implications on firm performance (Chandler, 1962). Recent research that has examined the relationship between strategy and structure has confirmed a moderating, rather than a mediating, effect of these constructs on firm performance (Mintzberg, 1990; Siggelkow and Levinthal, 2003). This research has highlighted the usefulness of examining interactions between salient dimensions of strategy and structure on firm performance. It has also established that alignment between these factors could be expected to result in higher performance.

\section{Fit Between Product Market Strategy and Business Model}

To evaluate the implications of business model and product market strategy on firm performance, we consider two main business model design themes - novelty-centered and efficiency-centered business models as introduced earlier - along with three product market strategy choices - cost leadership, differentiation (Porter, 1985), and the timing of entry into a market (Lieberman and Montgomery, 1988). As with business model design themes, these product market strategy choices are not mutually exclusive, nor are they exhaustive. For example, a firm's managers could choose to pursue simultaneously a strategy of product differentiation, cost leadership, and early market entry.

Which business model fits best with the firm's choice of product market strategy? In other words, what constitutes a good fit between these constructs? The literature on fit generally considers coherent configurations of design elements as good fit that manifest themselves as peaks in the performance 
landscape (Siggelkow, 2001). Concretely, two design elements (A and B) fit well if complementarities exist between them, that is, if the marginal benefit of $\mathrm{A}$ increases with the level of $\mathrm{B}$, and if the levels of A and B are adjusted optimally to achieve a local performance optimum (Milgrom and Roberts, 1995).

We next introduce a formal notation that allows us to investigate which combinations of business model design themes and product market strategies fit well. That notation helps us to theorize about these relationships in a more structured and rigorous way than would be possible through verbal theorizing. It is also advantageous because there exists little prior theorizing on business models on which we could draw in our theory development. The objective of this paper, however, is not to derive a fully specified model and closed form analytical solutions. Rather, we seek to provide a theoretically driven hypothesis development to guide our subsequent empirical analysis.

Since the total value created by a focal firm and its exchange partners is an upper limit for the value that can be appropriated by the focal firm (i.e., for its performance), the starting point of our analysis will be a framework that seeks to explain total value created. Within this framework the question can then be addressed how much value each exchange partner can extract. More specifically, we build on the model developed by Brandenburger and Stuart (1996) for value creation in a simple static setting with one firm, one customer, and one supplier. Extending this model, the total value created by a business model in a given time period can be expressed as the sum of the values created for all the participants in a business model, over all transactions that the business model enables. More formally, drawing on Besanko, Dranove and Shanley (1996), let $\mathrm{m}$ be an index ranging from 1 to $\mathrm{M}$, with M denoting the total number of market segments served by a focal firm through its business model, and let $P_{m}(t)$ be the price that a homogeneous customer from segment $\mathrm{m}$ pays for a good acquired in transaction $\mathrm{t}$, or for the right to participate in the transaction. Furthermore, let $\mathrm{B}_{\mathrm{m}}(\mathrm{t})$ denote the customer's perceived net benefit from participating in $\mathrm{t} . \mathrm{B}_{\mathrm{m}}(\mathrm{t})$ is net of the transaction, purchasing, and user costs that accrue to the customer (Besanko et al., 1996: 443); it can be thought of as the customer's willingness-to-pay. Consequently, the value created for a customer in transaction $\mathrm{t}$ can be written as

$$
\mathrm{V}_{\mathrm{m}}(\mathrm{t})=\mathrm{B}_{\mathrm{m}}(\mathrm{t})-\mathrm{P}_{\mathrm{m}}(\mathrm{t})
$$


The focal firm has adopted a business model of type $\mathrm{d}$, where $\mathrm{d}$ is a vector describing the extent to which the business model emphasizes the design themes novelty and efficiency. As well, it has adopted a product market strategy $\mathrm{s}$, where $\mathrm{s}$ is a vector describing the extent to which the firm emphasizes differentiation, cost leadership, and entry timing. For simplicity, denote that firm as $\mathrm{F}_{\mathrm{s}}^{\mathrm{d}} \equiv \mathrm{F}$. Denote the focal firm's suppliers and partners (other than customers) as $\mathrm{i}$, where $\mathrm{i}$ is an index ranging from 1 to $\mathrm{I}$, the total number of suppliers and partners in the business model. Let $\mathrm{R}_{\mathrm{i}}(\mathrm{t}, \mathrm{m})$ be the revenues that focal firm $\mathrm{F}$ gets from partner $\mathrm{i}$ in a particular transaction, $\mathrm{t}$, involving a customer from segment $\mathrm{m}$. Let $\mathrm{C}_{\mathrm{i}}(\mathrm{t}, \mathrm{m})$ denote the flow of revenues from $\mathrm{F}$ to $\mathrm{i}$, and let $\mathrm{OC}_{\mathrm{F}}(\mathrm{t}, \mathrm{m})$ be $\mathrm{F}$ 's opportunity costs for providing its own resources. Then the value created for firm $\mathrm{F}$ in transaction $\mathrm{t}$ involving a customer from segment $\mathrm{m}$ can be expressed as

$$
\mathrm{V}_{\mathrm{F}}(\mathrm{t}, \mathrm{m})=\mathrm{P}_{\mathrm{m}}(\mathrm{t})+\Sigma_{\mathrm{i}} \mathrm{R}_{\mathrm{i}}(\mathrm{t}, \mathrm{m})-\Sigma_{\mathrm{i}} \mathrm{C}_{\mathrm{i}}(\mathrm{t}, \mathrm{m})-\mathrm{OC}_{\mathrm{F}}(\mathrm{t}, \mathrm{m})
$$

Let us furthermore denote the opportunity costs of supplier or partner i of supplying resources (including, for example, complementary products or services) to $\mathrm{F}$ as $\mathrm{OC}_{\mathrm{i}}(\mathrm{t}, \mathrm{m})$. Then the value created for partner $\mathrm{i}$ in transaction $\mathrm{t}$ with a customer from segment $\mathrm{m}$ can be written as

$$
\mathrm{V}_{\mathrm{i}}(\mathrm{t}, \mathrm{m})=\mathrm{C}_{\mathrm{i}}(\mathrm{t}, \mathrm{m})-\mathrm{R}_{\mathrm{i}}(\mathrm{t}, \mathrm{m})-\mathrm{OC}_{\mathrm{i}}(\mathrm{t}, \mathrm{m})
$$

Assuming that the set of stakeholders in a business model comprises the focal firm, its customers, suppliers, and partners, and given that the total value created by the business model equals the sum of values created for all business model stakeholders, it follows that the total value created in transaction $\mathrm{t}$ is

$$
\mathrm{TV}(\mathrm{t}, \mathrm{m})=\mathrm{V}_{\mathrm{m}}(\mathrm{t})+\mathrm{V}_{\mathrm{F}}(\mathrm{t}, \mathrm{m})+\Sigma_{\mathrm{i}} \mathrm{V}_{\mathrm{i}}(\mathrm{t}, \mathrm{m})
$$

Inserting (1), (2) and (3) into (4) yields

$$
\mathrm{TV}(\mathrm{t}, \mathrm{m})=\mathrm{B}_{\mathrm{m}}(\mathrm{t})-\mathrm{OC}_{\mathrm{F}}(\mathrm{t}, \mathrm{m})-\Sigma_{\mathrm{i}} \mathrm{OC}_{\mathrm{i}}(\mathrm{t}, \mathrm{m})
$$

which is a generalized version of Brandenburger and Stuart's (1996) formula for total value created. Equation (5) focuses on a particular transaction, t, with a particular market segment, $\mathrm{m}$, rather than on a particular product or service. Finally, the total value created through a business model, TVC, is the value created over all market segments $\mathrm{m}$, and over all the types of transactions that the business model enables, where $t$ is an index ranging from 1 to $T$, and $T$ denotes the number of transaction types. $n(t, m)$ is the average number of transactions of type $t$ conducted with customers from segment $\mathrm{m}$ : 


$$
\mathrm{TVC}=\Sigma_{\mathrm{t}} \Sigma_{\mathrm{m}}[\mathrm{TV}(\mathrm{t}, \mathrm{m}) * \mathrm{n}(\mathrm{t}, \mathrm{m})]
$$

Inserting (5) into (6) yields

$$
\mathrm{TVC}=\Sigma_{\mathrm{t}} \Sigma_{\mathrm{m}}\left\{\left[\mathrm{B}_{\mathrm{m}}(\mathrm{t})-\mathrm{OC}_{\mathrm{F}}(\mathrm{t}, \mathrm{m})-\Sigma_{\mathrm{i}} \mathrm{OC}_{\mathrm{i}}(\mathrm{t}, \mathrm{m})\right]^{* \mathrm{n}}(\mathrm{t}, \mathrm{m})\right\}
$$

Similarly, the total value appropriated by the focal firm, TVA, can be expressed as

$$
\mathrm{TVA}=\Sigma_{\mathrm{t}} \Sigma_{\mathrm{m}}\left[\mathrm{V}_{\mathrm{F}}(\mathrm{t}, \mathrm{m}) * \mathrm{n}(\mathrm{t}, \mathrm{m})\right]
$$

Inserting (2) into (8) yields

$$
\text { TVA }=\Sigma_{\mathrm{t}} \Sigma_{\mathrm{m}}\left\{\left[\mathrm{P}_{\mathrm{m}}(\mathrm{t})+\Sigma_{\mathrm{i}} \mathrm{R}_{\mathrm{i}}(\mathrm{t}, \mathrm{m})-\Sigma_{\mathrm{i}} \mathrm{C}_{\mathrm{i}}(\mathrm{t}, \mathrm{m})-\mathrm{OC}_{\mathrm{F}}(\mathrm{t}, \mathrm{m})\right]^{*} \mathrm{n}(\mathrm{t}, \mathrm{m})\right\}
$$

TVA as a proxy for firm F's performance is contingent on F's business model, d, and its product market strategy, s. If $d$ and $s$ are choice variables of the firm, their impact on each term of the right hand side of equation (9) must be considered to understand their collective impact on TVA. Following Siggelkow (2002), a useful thought experiment for evaluating the fit between a particular business model design theme and a particular product market strategy is to consider whether the marginal value of a the business model design theme would be affected (in particular, whether it would increase) if a firm were to put more emphasis on the respective product market strategy (or vice versa). This thought experiment is consistent with the definition of fit as indicative of complementarity (Milgrom and Roberts, 1995; Siggelkow, 2001). Hence, in keeping with the aims of this paper, we proceed to explore the marginal effects of business model design themes and product market strategies on TVA.

Novelty-centered business model and TVA. A novelty-centered business model refers to the conceptualization and adoption of new ways of conducting economic exchanges among transaction participants. Novelty primarily aims at creating new types of transactions, i.e., increasing $\mathrm{T}$, but also at addressing new market segments, i.e., increasing M. It also strengthens the focal firm's bargaining power vis-à-vis other business model stakeholders (Zott and Amit, 2003). Consequently, stronger emphasis on novelty-centered business model will have a positive effect on $\mathrm{P}_{\mathrm{m}}(\mathrm{t})$ and will exert downward pressure on $\mathrm{C}_{\mathrm{i}}(\mathrm{t}, \mathrm{m})$ due to the increased bargaining power of the focal firm. Hence, we observe that a marginal 
increase in a firm's emphasis on a novelty-centered business model may affect TVA in equation (9) through $\mathrm{T}(+), \mathrm{M}(+), \mathrm{P}_{\mathrm{m}}(+)$, and $\mathrm{C}_{\mathrm{i}}(-) .^{3}$

We next examine the marginal effect on TVA of changing a particular product market strategy, followed by an analysis of the impact of such a change on the marginal value of novelty-centered business model on TVA.

First, consider product market differentiation. A stronger emphasis on differentiation will positively influence customers' willingness-to-pay, $\mathrm{B}_{\mathrm{m}}(\mathrm{t})$, and therefore make it easier for the focal firm to charge higher prices to customers, $\mathrm{P}_{\mathrm{m}}(\mathrm{t})$, and possibly lower the costs of suppliers, $\mathrm{C}_{\mathrm{i}}(\mathrm{t}, \mathrm{m})$ (Porter, 1985). Hence, a marginal increase in a firm's emphasis on differentiation may affect TVA through $\mathrm{P}_{\mathrm{m}}(+)$, and $\mathrm{C}_{\mathrm{i}}(-)$; this is how product market differentiation independently affects firm performance.

In addition, we consider the interaction between differentiation strategy and novelty-centered business model design. A focus on innovation in multiple domains (business model, product market strategy) may be mutually reinforcing, for example, by harnessing the creative energy of managers and employees, and by delivering new products and services to customers in new ways, thereby increasing the number of transaction types (T) as well as the number of market segments reached (M). Moreover, a firm that focuses all its activities and transactions on innovation may become an even more skillful innovator over time (Zott, 2003). Hence, we expect a positive joint effect on TVA: a marginal increase in the degree of product market differentiation will strengthen the marginal performance benefit of business model novelty.

Second, consider cost leadership. A stronger emphasis on cost leadership implies lower prices charged to customers, $\mathrm{P}_{\mathrm{m}}(\mathrm{t})$, as well as lower input and production costs, $\mathrm{C}_{\mathrm{i}}(\mathrm{t}, \mathrm{m})$ and $\mathrm{OC}_{\mathrm{F}}(\mathrm{t}, \mathrm{m})$ (Porter, 1985). Furthermore, new segments with customers highly sensitive to price can be addressed, thus raising

\footnotetext{
${ }^{3}$ The sign in brackets gives the expected direction of change in the respective variable from a marginal increase in novelty-centered business model design. E.g., $\mathrm{T}(+)$ means that $\mathrm{T}$ increases in novelty-centered design.
} 
M, and customers within given segments will be motivated to increase their number of repeat transactions, thus raising n. In other words, a marginal increase in a firm's emphasis on cost leadership may affect TVA through $\mathrm{P}_{\mathrm{m}}(-), \mathrm{C}_{\mathrm{i}}(-), \mathrm{OC}_{\mathrm{F}}(-), \mathrm{M}(+)$ and $\mathrm{n}(+)$; this is how cost leadership independently affects firm performance.

Moreover, a greater emphasis on cost leadership will also, on balance, enhance the marginal effect of novelty-centered business model on TVA. First, a more pronounced cost leadership approach interacts positively with the firm's strengthened bargaining power over its suppliers through increased novelty-centered business model as it puts additional downward pressure on $\mathrm{C}_{\mathrm{i}}$. Second, customers in new market segments will have two motives to be drawn to the firm and engage in transactions with it business model novelty and low cost product - which enhances the positive impact of novelty-centered business model on $\mathrm{M}$ and on $\mathrm{n}$. Therefore, overall, we expect a positive joint effect of cost leadership and novelty-centered business model on TVA.

Third, consider timing of market entry. Firms that enter markets earlier may enjoy considerable advantages. These stem from the creation of customer switching costs, brand awareness, and reputation, thus allowing these firms to charge higher prices, $\mathrm{P}_{\mathrm{m}}(\mathrm{t})$ (Lieberman and Montgomery, 1988). Early market entrants can also gain by learning (Arrow, 1974) and accumulating proprietary knowledge (Dierickx and Cool, 1989) and by pre-empting scarce resources, thus lowering their opportunity costs, $\mathrm{OC}_{\mathrm{F}}(\mathrm{t}, \mathrm{m})$ (Lieberman and Montgomery, 1988). As the early entrant attempts to address - and perhaps even create - a new market, the number of transactions, n, is likely to be limited. In other words, a marginal increase in a firm's emphasis on early market entry timing may affect TVA through $\mathrm{P}_{\mathrm{m}}(+)$, $\mathrm{OC}_{\mathrm{F}}(-)$, and $\mathrm{n}(-)$; this is how the timing of market entry independently affects firm performance.

In addition, a greater emphasis on early market entry will also, on balance, enhance the marginal effect of novelty-centered business model on TVA. Moving into a market earlier allows the firm to capture the rents from business model innovation, which can be considered entrepreneurial rents, i.e., rents that accrue between the introduction of an innovation and its diffusion (Rumelt, 1987). In particular, 
the positive effect of novelty-centered business model on $\mathrm{P}_{\mathrm{m}}$ may be more pronounced, and more sustainable if the firm enters a market early. Hence, we expect a positive joint effect on TVA.

In summary, the above analysis of novelty-centered business model suggests that coupling a novelty-centered business model with a product market strategy of differentiation, cost leadership, or early market entry results in good fit. The following hypotheses (H1 - H3) capture these relationships.

Hypothesis 1: A novelty-centered business model and a strategy of product market differentiation interact positively to affect firm performance.

Hypothesis 2: A novelty-centered business model and a strategy of product market cost leadership interact positively to affect firm performance.

Hypothesis 3: A novelty-centered business model and a strategy of early market entry interact positively to affect firm performance.

Hypothesis 1 is surprising, because intuitively one might think that new products delivered to customers through a novel business model could be too much of a good thing. Hypothesis 2 is also counterintuitive, because one might at first think that novel business model design and cost leadership strategy may lead firms to be "caught in the middle" (Porter, 1985). Hypothesis 3, finally, posits that first mover advantages also accrue to business model innovators, and not only to product and service innovators, which is an important hypothesis to test empirically.

Efficiency-centered business model and TVA. An efficiency-centered business model aims at reducing transaction costs for all transaction participants. This explains the likely negative effects of a marginal emphasis in such a business model on $\mathrm{OC}_{\mathrm{F}}(\mathrm{t}, \mathrm{m})$. By reducing transaction costs, an efficiencycentered business model may also lead to higher transaction volume, $\mathrm{n}(\mathrm{t}, \mathrm{m})$; more new customers will be drawn to transact with the focal firm, and existing customers may transact more frequently as a result of 
the lowered transaction costs. Hence, a marginal increase in a firm's emphasis on an efficiency-centered business model may affect TVA through $\mathrm{OC}_{\mathrm{F}}(-)$, and $\mathrm{n}(+){ }^{4}$

Next, to evaluate the possible fit between an efficiency-centered business model and a particular choice of business strategy, we examine whether the marginal value of an efficiency-centered business model would increase if a firm were to put more emphasis on a particular product market strategy.

First, consider the strategy of differentiation. As shown above, a marginal increase in a firm's emphasis on product market differentiation may affect TVA independently primarily through $\mathrm{P}_{\mathrm{m}}(+)$, and $\mathrm{C}_{\mathrm{i}}(-)$. It is not clear per se whether and how product differentiation would affect the marginal effect of an efficiency-centered business model on TVA through $\mathrm{OC}_{\mathrm{F}}$, and $\mathrm{n}$. Hence, the joint effect of differentiation and an efficiency-centered business model on TVA is indeterminate.

Second, consider cost leadership. We have seen that a marginal increase in a firm's emphasis on cost leadership may affect TVA independently through $\mathrm{P}_{\mathrm{m}}(-), \mathrm{C}_{\mathrm{i}}(-), \mathrm{OC}_{\mathrm{F}}(-), \mathrm{n}(+)$ and $\mathrm{M}(+)$. In addition, a focus on low costs in multiple domains (business model, product market strategy) may be mutually reinforcing by focusing managers' efforts on cost savings across transactions, products and processes and by delivering low cost products and services to customers in low cost ways, thereby reinforcing the marginal effects of efficiency-centered design on TVA through $\mathrm{OC}_{\mathrm{F}}$ and $\mathrm{n}$. Moreover, a firm that focuses in all its activities and transactions on cost reductions may become even more skillful at reducing costs over time, thus decreasing $\mathrm{OC}_{\mathrm{F}}$ even further. Hence, we expect a positive joint effect of cost leadership and an efficiency-centered business model on TVA.

Third, consider timing of market entry. As shown above, a marginal increase in a firm's emphasis on early market entry timing may affect TVA independently through $\mathrm{P}_{\mathrm{m}}(+), \mathrm{OC}_{\mathrm{F}}(-)$, and $\mathrm{n}(-)$. However, it is not clear per se whether and how early market entry timing, on balance, affect the marginal benefit of

\footnotetext{
${ }^{4}$ Again, the sign in brackets gives the expected direction of change in that variable from a marginal increase in the degree of efficiency-centered business model design.
} 
an efficiency-centered business model. We expect, therefore, that the joint effect of early market entry and an efficiency-centered business model on TVA is indeterminate.

In summary, the above analysis suggests that coupling an efficiency-centered business model with a product market strategy of cost leadership represents good fit, whereas the fit with either a product market strategy of differentiation or with early market entry cannot be clearly predicted. These theoretical considerations are captured by the following hypothesis.

Hypothesis 4: An efficiency-centered business model and a strategy of product market cost leadership jointly interact positively to affect firm performance.

\section{DATA AND METHODS}

\section{Sample}

We collected data on a sample of firms that had gone public in Europe or in the U.S. between April 1996 and May 2000. This sample selection strategy enabled us to create a data set of about 300 firms that conducted part of their business over the Internet (e.g., firms like eTrade, Guess, and Priceline), and hence served as fertile ground to investigate Internet-enabled business models. These firms were likely to experiment with, and take advantage of, the possibilities that advanced information and communication technologies offered for the design of their business models. Consistent with the observation that such business models span firm and industry boundaries (Amit and Zott, 2001) we constructed a cross-industry sample.

We randomly sampled 170 firms on their business model characteristics and product market strategies. We considered companies that had recently gone public because at the time we conducted the study, there were not many established firms in the public domain that used the Internet to enable their business models. Furthermore, relatively young firms have fewer lines of business than older, more established corporations, and their business models are therefore easier to describe and measure as they involve fewer transaction types and exchange partners. Data collection from initial public offering 
documents also ensured the availability and consistency of the data on business models and business strategies; it is an acknowledged method for studying firms' strategies (e.g., Dowling and McGee, 1994).

\section{Data Collection}

The data collection proceeded in two stages. In the first stage, we built composite scales for business model design themes, and we identified and measured the relevant items on the basis of a content analysis of IPO prospectuses. In the second stage, we followed a similar procedure to build composite scales for, and measure relevant dimensions of product market strategies.

To determine the scales for the business model design themes, we relied on the measurement scales developed by Zott and Amit (2003). To collect the data, we hired eleven part- or full-time research assistants (primarily MBA students), and we trained them as expert raters to analyze assigned sample companies. We thus built on the common technique of using expert panelists in management research (see, for example, MacCormack et al., 2001). We carefully selected our raters and trained them in data collection and data analysis. On average, it took a rater about two days to collect data on a given business model, to understand the model, and to assess it. Data sources included primarily IPO prospectuses (Dowling and McGee, 1994), but also annual reports, investment analysts' reports, and web sites. The business model data were collected from May 2000 to June 2001. During that time period, we were able to take one measurement of the design themes for each of the business models in our sample. The lack of readily available data on business models thus made us draw on primary sources of data and construct a unique, manually collected data set; it also prevented us from collecting time-series data, which is preferable in studies that can draw on secondary sources of data (Bowen and Wiersema, 1999).

We validated inter-rater reliability by assigning a randomly chosen business model to two different expert raters (each of whom was assigned to a different project manager), and by conducting a pair-wise comparison of responses, yielding a Cronbach alpha of 0.81 , and a Pearson correlation coefficient of 0.72 . Raters were in broad agreement with each other for $82 \%$ of the individual items. We repeated the test periodically, and we found that all indicators of reliability further improved. 
With respect to product market strategy scales, we drew on the strategy and management literatures to establish measures of product market positioning through differentiation, cost leadership, and timing of market entry. We found that most of the empirical work on Porter's (1985) generic strategies, for example, had been conducted on the basis of surveys administered to managers. A few researchers (e.g., Dowling and McGee, 1994) have used IPO prospectuses to measure these items. We then adapted these survey-based instruments so as to analyze the content of our primary data source.

We iteratively selected items to measure product market strategy dimensions. We started with 51 items derived from the literature that measured various aspects of generic firm-level strategy. After pilottesting these items on our sample firms, we refined some items and dropped others, mainly on the basis of data availability. As a result of this process, and following further scale purification, we retained three items referring to differentiation and four items referring to cost leadership. We also retained a singleitem measure for market-entry timing. Two raters then used these measures to analyze independently all 170 firms in our sample. The business strategy data were collected during the fourth quarter of 2003, using the same sources that we had consulted earlier to measure the business model design themes. Thus, our data reflect the product market strategies that sample firms had adopted between 2000 and 2001 .

Inter-rater reliability on the business strategy measures was established by conducting a pair-wise comparison of responses for five randomly chosen firms, yielding a Cronbach alpha of 0.92, and a Pearson correlation coefficient of 0.91 . Raters were in exact agreement with each other on $77 \%$ of the individual items (on a five point scale). All initial differences were resolved through discussions, so the final agreement percentage was $100 \%$.

\section{Econometric Modeling and Estimation Approach}

We conducted a Confirmatory Factor Analysis and a Partial Least Squares regression analysis in order to establish the discriminant validity of our business model and product market strategy constructs. We then proceeded to analyze the data using multivariate regression techniques. We confirmed that conventional assumptions underlying OLS regression analysis held in our data set. First, after performing a logarithmic transformation of our dependent variable, we found that the null hypothesis of normality 
could not be rejected at the 5\% level of significance using a Shapiro-Wilk test. Second, being concerned with heteroscedasticity in a cross-sectional study (see Bowen and Wiersema, 1999), we used White's general test for homoscedasticity to detect evidence of heteroscedasticity. We corrected the p-values and t-statistics of estimates using White's variance-covariance matrix for those models in which heteroscedasticity appeared to be present (White, 1980).

As a third measure to verify the validity of our model, we tested for multicollinearity among independent variables by calculating Variance Inflation Factors (VIF) (Kleinbaum et al., 1998) in regression models that contained only first-order terms before mean-centering our measures. The VIF levels that we observed were smaller than 2 , hence much smaller than the critical threshold of 10 , thus eliminating the concern about multicollinearity among first-order terms in the regression analysis. Multicollinearity may, however, arise due to the introduction of the interaction term, in which case meancentering can be applied to all first- and second-order variables as a standard and valid procedure to attenuate multicollinearity (Aiken and West, 1991). Interaction terms are entered as orthogonalized effects, and this approach yields interaction variables that are uncorrelated with their component variables. The VIF levels that we observed in regression models containing first- and second-order terms after mean-centering our first-order measures were again all smaller than 2. Our model specification, therefore, proved robust to multicollinearity.

\section{Independent Variables}

Two latent variables characterize the design themes of a business model (novelty and efficiency), and another three latent variables characterize the product market positioning of the firm (differentiation, cost leadership, and timing of entry). We used 13 items for novelty, 11 items for efficiency, 3 items for differentiation, 4 items for cost leadership, and 1 item for timing of market entry (see the Appendix for details on the scales). Given the difficulty of obtaining objective measures of business models and product market strategy, we deemed the use of perceptual measures obtained from expert raters appropriate (Dess and Robinson, 1984). The strength of each of these items was measured using five point Likert-type scales, which we coded into a standardized score. After coding, we aggregated the item scores for each 
composite scale into an overall score using equal weights (see Mendelson, 2000). This process yielded distinct quantitative measures of business model and product market strategy.

We validated the internal consistency and reliability of our measures using standardized Cronbach alpha coefficients, which were 0.71 for the business model novelty measure, 0.70 for the business model efficiency measure, 0.66 for the differentiation strategy measure, and 0.76 for the cost leadership strategy measure. Hence, our measures sufficiently satisfy Nunnally's (1978) guidelines, which suggest 0.7 as a benchmark for internal consistency.

\section{Dependent Variables}

A firm's stock-market value reflects the market's expectations of future cash flows to shareholders, and hence can be viewed as a measure of perceived firm performance, as opposed to realized performance, which is typically embodied in historical measures of firm profitability (e.g., ROI, ROA). Given the level of uncertainty often associated with the true prospects of firms that had a recent Initial Public Offering, perceived performance operationalized as stock market value is a measure that is particularly germane in such a setting (Stuart et al., 1999). Measures of realized performance, such as ROI, ROA, or Tobin's q, are less appropriate for these firms, which often have negative earnings, few tangible assets, and low (or even negative) book values.

We took measurements of the dependent variable at various time periods: annual average 2000, and average during the fourth quarter (Q4) of 2000. These time periods correspond well to the measurement of the independent variables. Since most firms in our sample have relatively low levels of debt, the market value of a firm's equity is a good approximation of the market value of the whole firm. We measured the market value of equity at a given date as the number of shares outstanding multiplied by the firm's stock price, taken from the combined CRSP and Datastream databases. We then took the logarithm of the market value of the equity in order to comply with the normality assumption of OLS. Since we are controlling in our analysis for the size and age of the focal firm, as well as for a range of firm- and industry-related factors (see below), we are confident that the differences in the market value of equity among our sample firms capture performance differences. 


\section{Control Variables}

We included further factors that might influence the market value of a firm's equity as control variables in the analysis because their omission might confound the analysis. On the firm level, we included variables that controlled for the age and size (i.e., the number of employees) of the firm. We also controlled for additional dimensions of a firm's product market strategy, such as the mode of market entry, and its product and market scope (see the Appendix for details on these variables). On the industry level of analysis we controlled for the degree of competition and estimated market size. Our raters measured the degree of competition on a four-point Likert scale based on information found in annual reports, prospectuses, competitors' SEC documents and web sites, benchmark studies, Hoovers' Database (which lists each focal firm's main competitors), as well as investment analysts' reports. The data on market size were obtained from Forrester research reports and from the U.S. Department of Commerce. We also controlled for quadratic interaction effects among our main variables, to establish the linear nature of the hypothesized effects.

\section{RESULTS}

\section{Descriptive Statistics}

Table 2 provides an overview of the data we use in this study. We note that our sample firms have an average age of seven years (median of 4.3 years) in 2000, and a median of 270 employees. We also note the large variance among sample firms as evidenced by the median, minimum, and maximum values of these variables. Furthermore, our sample firms draw from relatively broad and highly competitive market segments and focus on a narrow array of products. There are few early entrants into the market among our sample firms. Our sample, thus, consists mostly of emerging growth companies that address relatively established markets.

\section{[INSERT TABLE 2 ABOUT HERE]}

Table 2 also lists the Pearson correlations among the variables used in the regression analysis. The correlations between a novelty-centered business model and a differentiation strategy (0.148), and between an efficiency-centered business model and a cost leadership strategy $(-0.064)$ are low, which 
supports the argument that business model design themes and product market strategies are distinct. We also note that while some correlations among explanatory variables are significant and relatively high (e.g., between age and entry mode: 0.488 ), they do not appear to pose a multicollinearity problem as the Variance Inflation Factors (VIF) are low for all these variables.

\section{Confirmatory Factor Analysis and Partial Least Squares Regression}

A basic premise of this study is that the business model is distinct from product market strategy (see the corollary stated earlier). Since the business model is a relatively new construct for strategic management research, it is incumbent upon us to empirically validate that claim through establishing the discriminant validity of our main constructs. To do so, we performed two sets of analyses: confirmatory factor analysis (CFA), and partial least squares regression (PLS). If the results from these analyses converge, then this provides strong support for our corollary.

We first conducted the confirmatory factor analytic method proposed by Gatignon et al. (2002). The method consists in selecting pairs of constructs and then conducting CFA for each pair. In applying this method, we first ran a CFA for each pair of factors in an unconstrained measurement model with the two factors. In this first model, the correlation between the factors was estimated. For example, take novelty and differentiation as the chosen pair of factors. Novelty traits loaded onto the novelty factor, and the differentiation traits loaded onto the differentiation factor. Table 3 depicts the results from this analysis in the rows where the correlation between the factors is reported as freely estimated (i.e., not set equal to 0 or 1). For example, the estimated correlation between novelty and differentiation was 0.19 .

\section{[INSERT TABLE 3 ABOUT HERE]}

We then ran a CFA on a measurement model with only one factor, where the correlation between the constructs of interest was constrained to be 1 . If the unconstrained model where the correlation is freely estimated improves the fit significantly compared to the constrained model, the two constructs are distinct from each other, although they still can be significantly correlated (Gatignon et al. 2002; Gatignon 2003). To illustrate this, consider novelty and differentiation. The results from the CFA demonstrate that noveltycentered business model and differentiation in product markets are distinct constructs, although they are 
positively correlated. This is confirmed by a significantly (at the 0.01 level) improved confirmatory factor analytic model when the correlation is estimated, compared to a measurement model where the correlation is constrained to 1 (chi-squared $=260-186=74$, degrees of freedom $=104-103=1)$. As Table 3 shows, we obtain similar results for all other pairs involving generic product market strategies and business model design themes, which provides support for our corollary ["Business models (as, for example, measured by design themes) are distinct from product market strategies (as, for example, measured by generic strategies)"].

In addition to CFA, the literature suggests partial least squares (PLS) as another method for assessing discriminant validity. Using PLS, one can determine whether a construct shares more variance with its measures than it shares with other constructs in the model (Hulland, 1999). This is achieved by (1) calculating the square roots of the Average Variance Extracted (AVE) values, which measure the average variance shared between a construct and its measures, and by (2) calculating the correlations between different constructs. A matrix can then be constructed where the square root of AVE is in the diagonal, and the correlations between the constructs are in the off-diagonal. This matrix is shown in Table 4. For adequate discriminant validity, the diagonal elements should be greater than the off-diagonal elements in the corresponding rows and columns (Fornell and Larcker, 1981). This is the case here, which is further evidence in support of the discriminant validity of our constructs.

\section{[INSERT TABLE 4 ABOUT HERE]}

We note that the CFA can also be used to assess the convergent validity of the constructs (Gatignon et al., 2002; Gatignon, 2003). For this, a measurement model where the correlation between the two constructs is estimated and a model where the correlation is constrained to be 0 are compared. A significant improvement in fit (moving from zero to estimated correlation) would indicate that the two constructs are indeed related, which would confirm convergent validity. Using as an illustration again the example of novelty and differentiation in Table 3, the results from the CFA demonstrate that a novelty-centered business model and product market differentiation are independent constructs. The confirmatory factor analytic model when the correlation is estimated, compared to a measurement model where the correlation 
is constrained to 0 , is not significantly improved (chi-squared $=189-186=3$, degrees of freedom $=104-$ 103 1). This same qualitative result holds for all pairs of generic strategies and business model design themes.

\section{Hierarchical OLS Regressions}

Table 5 depicts the results from selected hierarchical OLS regression runs. Panel A reports the full results for the models that included the interaction between a novelty-centered business model and a strategy of differentiation. In Panel A, the top display refers to regressions that used the logarithm of market value averaged over the fourth quarter of 2000 , and the bottom display refers to regressions that used the logarithm of market value averaged over the entire year 2000. Panel B shows the main results for the other interactions of interest.

\section{[INSERT TABLE 5, Panels A \& B HERE]}

Table 5 Panel A supports the prediction made in Hypothesis 1 that coupling a novelty-centered business model with a differentiation product market strategy represents good fit; these variables jointly produce a significant positive effect on performance -- for both dependent variables used (see the top and bottom display of the Panel) -- in most models that we ran. Furthermore, Table 5 Panel B (which summarizes models that structurally similar to those shown in Table 5 Panel A) supports the hypothesized good fit between novelty-centered business models and cost leadership strategy according to Hypothesis 2, and between novelty-centered business models and early market entry timing according to Hypothesis 3 . Our data produce a positive coefficient on the relevant interaction terms in all of our regressions. That coefficient is statistically significant at the $5 \%$ level in a majority of the models that exhibit an adequate Fvalue.

To corroborate and further examine the results from these models, we performed post-hoc analysis using plotting techniques suggested by Aiken and West (1991). Consider, for example, the results on the interaction between product market differentiation and novelty-centered business model design reported in the top panel of Table 5 Panel A, Model 4. The plots of differentiation on performance for different values of novelty (mean value, one standard deviation below the mean, one standard deviation above the mean) 
revealed that for higher values of novelty, the slope of the plotted regression line was larger, and positive (see Figure 1). The plots of novelty on performance for different values of differentiation (mean value, one standard deviation below the mean, one standard deviation above the mean) revealed similar qualitative results, as well as the additional insight that the observed positive interaction effect between differentiation strategy and novelty-centered business model design is powerful: it trumps the independent effect of novelty-centered design on performance (see Figure 2). The slope of the regression line is negative for low values of differentiation, and becomes positive for high values of differentiation. In other words, the plots shown in Figures 1 and 2 are consistent with Hypothesis $1 .^{5}$

\section{[INSERT FIGURES 1 AND 2 HERE]}

Our analyses of the other significant interaction effects reported in Table 5 Panel B yielded analogous results. For space reasons these analyses are not reported here (but they are available upon request from the authors).

Regarding the fit between efficiency-centered business models and product market strategies, we note that our empirical analysis (as shown in Table 5 Panel B) did not support the predicted good fit between efficiency-centered business models and cost leadership strategy (Hypothesis 4); it produced insignificant results. Moreover, we performed additional analyses not shown in more detail here, in which we did not find any statistically significant interaction terms involving efficiency-centered business models and product market differentiation or early market timing, which suggested neither good nor bad fit between these variables. This is consistent with the predictions from our model.

We note that even when the interaction terms reported in Table 5 were statistically significant, the

\footnotetext{
${ }^{5}$ The slopes of the simple regression lines shown in Figures 1 and 2 differ significantly from one another. Aiken and West (1991: pp.19ff) demonstrate formally that the corresponding t-test is equivalent to testing the significance of the coefficient of the interaction term in the regression. Since we observed a statistically significant coefficient of the interaction term in the regression (see Table 5 Panel A), the corresponding slopes are significantly different from each other in the plots provided in Figures 1 and 2.
} 
coefficients on some of the corresponding main variables were insignificant. This corroborates the importance of considering interactions between product market strategies and business models, over and above their independent effects on firm performance.

\section{DISCUSSION AND CONCLUSION}

Our theoretical and empirical analysis reveals that a firm's product-market strategy and its business model are distinct constructs that affect the firm's market value. We show the discriminant validity of the business model construct and, using hierarchical OLS regression techniques, we find significant effects of its interaction with product market strategy on the perceived performance of firms, as measured by market capitalization. More specifically, we find empirical support for the theoretical predictions about the positive and significant interactions between novelty-centered business models and various product market strategies. With respect to efficiency-centered business models, however, our analysis did not provide support for the hypothesized positive interaction between efficiency-centered business model and cost leadership strategy. Our other empirical findings on efficiency-centered business models were consistent with the theoretical analysis: our empirical analysis did not reveal any complementarities with a differentiation strategy or with the timing of entry, and indeed no clear predictions can be made with respect to any such relationship.

We believe that our study makes several important contributions to the strategic management literature. First, we establish the contingent role a firm's business model in the determination of its market capitalization. In doing so, we extend the scholarly inquiry into structure as a contingency factor. Whereas the traditional focus in the received literature has been on the firm's internal administrative structure, our analysis centered on boundary-spanning transactions between a focal firm and its ecosystem of partners, customers, and suppliers. We show that adopting a broader view of organizations, one that transcends traditional firm boundaries, can be valuable for understanding wealth creation and performance. By doing so, our study may inspire new research on the relationship between strategy and structure, and on the boundaries of firms. 
Second, we theoretically explore the fit between a focal firm's business-level competitive strategy and the design themes of its business model. We elaborate on the notion of "good fit" between these constructs by offering a formal notation and by performing a marginal effects analysis within our framework. This constitutes a theoretical extension of the literature on the fit between strategy and structure.

Third, by empirically testing the derived theoretical hypotheses our study points to the need to examine the firm's business model as a source of competitive advantage. We suggest that competitive advantage can emerge from superior product-market positioning, as well as from the firm's business model. Indeed, the empirical results presented in this paper show that both can enhance the firm's performance, independently as well as jointly, which supports previously held conjectures (e.g., Christensen, 2001). Our study thus points to the need to investigate competition among various business models within an industry (Markides and Charistou, 2004) in addition to considering product market competition. Such rivalry on a business model level may have implications both for the wealth-creation potential of a given business model and for value capture by the focal firm. In order to better understand these phenomena, we need to know more about the strategic effects of business models and how business models influence the positioning of firms in their competitive environment.

Finally, our study raises the issue of timing of business model and product market strategy design. Business model and product market strategy may be simultaneously determined. For example, when entrepreneurs define and refine their business models, they may concurrently identify customer needs and map them against the products and services offered by competitors (McGrath and MacMillan, 2000). However, it is also conceivable that product market strategy follows business model design, or vice versa. Little research has been conducted so far on how business models evolve and in particular how they co-evolve with the product market strategy of the firm. In this study, we hope to have laid some of the foundations that are necessary to fruitfully explore these new avenues for research. 


\section{REFERENCES}

Aiken LS, West SG. 1991. (Paperback 1996). Multiple Regression: Testing and Interpreting Interactions. Sage: Thousand Oaks CA.

Amburgey TL, Dacin T. 1994. As the left foot follows the right? The dynamics of strategic and structural change. Academy of Management Journal 37: 1427-1452.

Amit R, Zott C. 2001. Value creation in e-business. Strategic Management Journal 22: 493-520.

Arrow K. 1962. Economic welfare and the allocation of research for invention. In R. Nelson (Ed.), The Rate and Direction of Inventive Activity: Economic and Social Factors: 609-625. Princeton University Press: Princeton.

Besanko D, Dranove D, Shanley M. 1996. Economics of Strategy. John Wiley \& Sons: New York. Bowen HP, Wiersema MF. 1999. Matching method to paradigm in strategy research: Limitations of cross-sectional analysis and some methodological alternatives. Strategic Management Journal 20: $625-636$.

Bower JL. 1970. Managing the Resource Allocation Process: A Study of Corporate Planning and Investment. Harvard Business School Press: Boston MA.

Brandenburger AM, Nalebuff BJ. 1996. Co-opetition. Doubleday: New York.

Brandenburger AM, Stuart H. 1996. Value-based business strategy. Journal of Economics and Management Strategy 5: 5-25.

Chandler A. 1962. Strategy and Structure: Chapters in the History of American Industrial Enterprise. MIT Press: Cambridge.

Christensen CM. 2001. The past and future of competitive advantage. MIT Sloan Management Review 42: $105-109$.

Claycomb C, Germain R, Droege C. 2000. The effects of formal strategic marketing planning on the industrial firm's configuraion, structure, exchange patterns, and performance. Industrial Marketing Management: 29: 219-234. 
Dess GG, Robinson R. 1984. Measuring organizational performance in the absence of objective measures. Strategic Management Journal 5: 265-73.

Dierickx I, Cool K. 1989. Asset stock accumulation and sustainability of competitive advantage. Management Science 35:1504-1511.

Donaldson L. 1996. The normal science of structural contingency theory. In S.R. Clegg, C. Hardy, W.R. Nord (Eds.), Handbook of Organization Studies: 57-76. Sage: London.

Doty DH, Glick WH, Huber GP. 1993. Fit, equifinality, and organizational effectiveness: A test of two configurational theories. Academy of Management Journal 36: 1196-1250.

Dowling MJ, McGee JE. 1994. Business and technology strategies and new venture performance: A study of the telecommunications equipment industry. Management Science 40: 1663-1677.

Dyer JH, Singh H. 1998. The relational view: cooperative strategy and sources of interorganizational competitive advantage. Academy of Management Review 23: 660-679.

Fornell C, Larcker DF. 1981. Evaluating structural equation models with unobservable variables and management error. Journal of Marketing Research 18: 39-50.

Galbraith, JR. 1977. Organization Design. Addison-Wesley Publishing Company: Reading.

Gatignon H. 2003. Statistical Analysis of Management Data. Kluwer Academic Publishers: Boston.

Gatignon H, Tushman M, Smith W, Anderson P. 2002. A structural approach to assessing innovation: construct development of innovation locus, type and characteristics. Management Science 48: 1103-1122.

Geoffrion AM, Krishnan R. 2003. E-business and management science: Mutual impacts (Part 1 of 2). Management Science 49: 1275-1286.

Ghaziani A, Ventresca MJ. 2005. Keywords and cultural change: Frame analysis of business model public talk 1975-2000. Sociological Forum 20: 523-559.

Gulati R, Nohira N, Zaheer A. 2000. Strategic networks. Strategic Management Journal 21: 203-215.

Hann I, Terwiesch C. 2003. Measuring the frictional costs of online transactions: The case of a nameyour-own-price channel. Management Science 48: 1563-1579. 
Hulland J. 1999. Use of partial least squares (PLS) in strategic management research: A review of four recent studies. Strategic Management Journal. 20: 195-204.

Kleinbaum DG, Kupper LL, Muller KE, Nizam A. 1998. Applied Regression Analysis and Other Multivariable Methods ( $3^{\text {rd }}$ ed.). Duxberry Press: Pacific Grove CA.

Lieberman M, Montgomery D. 1988. First-mover advantages. Strategic Management Journal 9: 41-58.

MacCormack A, Verganti R, Iansiti M. 2001. Developing products on "Internet time": The anatomy of a flexible development process. Management Science 47: 133-150.

Magretta J. 2002. Why business models matter. Harvard Business Review 80: 86-92.

Markides C, Charistou CD. 2004. Competing with dual business models: A contingency approach. Academy of Management Executive 18: 22-36.

McGrath R, MacMillan I. 2000. The Entrepreneurial Mindset. Harvard Business School Press: Boston.

Mendelson H. 2000. Organizational architecture and success in the information technology industry. Management Science 46: 513-529.

Meyer AD, Tsui AS, Hinings CR. 1993. Guest co-editors' introduction: Configurational approaches to organizational analysis. Academy of Management Journal 36: 1175-1195.

Miles RE, Snow CC. 1978. Organization Structure, Strategy, and Process. McGraw-Hill: New York.

Milgrom P, Roberts J. 1995. Complementarities and fit: strategy, structure, and organizational change in manufacturing. Journal of Accounting and Economics 19: 179-208.

Miller D. 1988. Relating Porter's business strategies to environment and structure. Academy of Management Journal 31: 280-308.

Mintzberg HT. 1979. The Structuring of Organizations. Prentice-Hall: Englewood Cliffs.

Mintzberg HT. 1990. The design school: reconsidering the basic premises of strategic management. Strategic Management Journal 11: 171-195.

Nadler DA, Tushman ML. 1997. Competing by Design. Oxford University Press: Oxford.

Normann R. 2001. Reframing Business: When The Map Changes The Landscape. Wiley: Chichester.

Nunnally JC. 1978. Psychometric Theory. McGraw-Hill: New York. 
Porter ME. 1985. Competitive Advantage: Creating and Sustaining Superior Performance. Free Press/MacMillan: New York.

Rumelt R. 1987. Theory, strategy, and entrepreneurship. In D. J. Teece (Ed.), The Competitive Challenge: 137-158. Ballinger Publishing Company: Cambridge.

Santos FM, Eisenhardt KM. 2005. Organizational boundaries and theories of organization. Organization Science 16: 491-508.

Siggelkow N. 2001. Change in the presence of fit: the rise, the fall, and the renaissance of Liz Claiborne. Academy of Management Journal 44: 838-857.

Siggelkow N. 2002. Evolution toward fit. Administration Science Quarterly 47: 125-159.

Siggelkow N, Levinthal DA. 2003. Temporarily divide to conquer: centralized, decentralized, and reintegrated organizational approaches to exploration and adaptation. Organization Science 14: $\underline{650-669 .}$

Stuart TE, Hoang H, Hybels RC. 1999. Interorganizational endorsements and the performance of entrepreneurial ventures. Administrative Science Quarterly 44: 315-349.

White H. 1980. A heteroskedasicity-consistent covariance matrix estimator and a direct test for heteroscedasticity. Econometrica 48: 817-838.

Williamson OE. 1975. Markets and Hierarchies - Analysis and Antitrust Implications. The Free Press: New York.

Yin X, Zajac E. 2004. The strategy/governance structure fit relationship: theory and evidence in franchising arrangements. Strategic Management Journal 25: 365-383.

Zott C. 2003. Dynamic capabilities and the emergence of intra-industry differential firm performance: insights from a simulation study. Strategic Management Journal 24: 97-125.

Zott C, Amit R. 2003. Business model design and the performance of entrepreneurial firms. Working Paper 2003/94/ENT/SM/ACGRD 4. INSEAD: Fontainebleau France.

Zott C, Bancerek I. 2004. Webraska (A) \& (B). INSEAD Case Studies. 
TABLE 1: Business Model, And Product Market Strategy

\begin{tabular}{|c|c|c|}
\hline & Business Model & Product Market Strategy \\
\hline Definition & $\begin{array}{l}\text { Pattern of the firm's transactions with its } \\
\text { external stakeholders }\end{array}$ & $\begin{array}{l}\text { Pattern of managerial actions that explain } \\
\text { how firm achieves and maintains } \\
\text { competitive advantage through positioning } \\
\text { in product markets }\end{array}$ \\
\hline $\begin{array}{l}\text { Main } \\
\text { Questions } \\
\text { Addressed }\end{array}$ & $\begin{array}{l}\text { How to connect with factor and product } \\
\text { markets? } \\
\text { Who are the parties that can be } \\
\text { brought together to exploit a } \\
\text { business opportunity, and how can } \\
\text { they be linked to the focal firm to } \\
\text { enable transactions? (i.e., what are } \\
\text { the exchange mechanisms?) } \\
\text { - What information or goods are } \\
\text { exchanged among the parties, and } \\
\text { what resources and capabilities are } \\
\text { needed to enable the exchanges? } \\
\text { How are the transactions between } \\
\text { the parties controlled, and what are } \\
\text { the incentives for the parties? }\end{array}$ & $\begin{array}{l}\text { What positioning to adopt against rivals? } \\
\text { - What kind of generic strategy to } \\
\text { adopt (i.e., cost leadership and/or } \\
\text { differentiation)? } \\
\text { - When to enter the market, and } \\
\text { how to enter it? }\end{array}$ \\
\hline $\begin{array}{l}\text { Unit of } \\
\text { Analysis }\end{array}$ & Focal firm and its exchange partners & Firm \\
\hline Focus & $\begin{array}{l}\text { Externally oriented: focus on firm's } \\
\text { exchanges with others }\end{array}$ & $\begin{array}{l}\text { Internally/externally oriented: focus on } \\
\text { firm's activities and actions in light of } \\
\text { competition }\end{array}$ \\
\hline
\end{tabular}


TABLE 2: Pearson Correlations and Descriptive Statistics

\begin{tabular}{|c|c|c|c|c|c|c|c|c|c|c|c|c|c|c|}
\hline $\begin{array}{l}\text { Variable Name } \\
\text { (Acronym) }\end{array}$ & $\begin{array}{l}\frac{B}{0} \\
\frac{0}{0} \\
\dot{Z}\end{array}$ & 异 & & 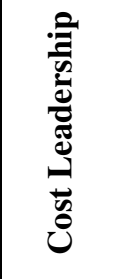 & 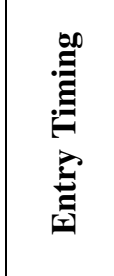 & 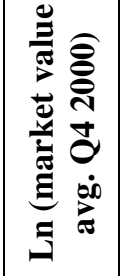 & 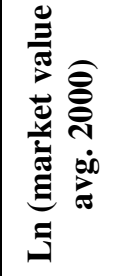 & ن̃ & 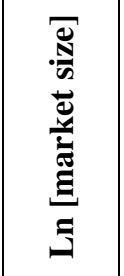 & 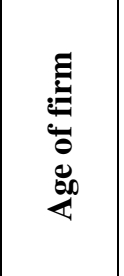 & 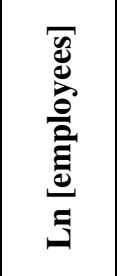 & 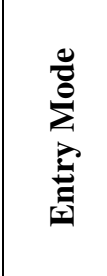 & 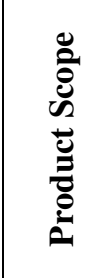 & 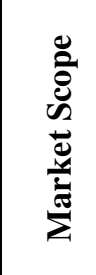 \\
\hline \multicolumn{15}{|l|}{ Indep. Var. } \\
\hline Novelty & 1.000 & & & & & & & & & & & & & \\
\hline Efficiency & $0.193 *$ & 1.000 & & & & & & & & & & & & \\
\hline Differentiation & $0.148^{\dagger}$ & 0.053 & 1.000 & & & & & & & & & & & \\
\hline Cost Leadership & -0.013 & -0.064 & -0.061 & 1.000 & & & & & & & & & & \\
\hline Entry Timing & $0.238 * *$ & 0.004 & $0.197 *$ & $0.164 *$ & 1.000 & & & & & & & & & \\
\hline \multicolumn{15}{|l|}{ Dependent Var. } \\
\hline $\begin{array}{l}\text { Ln (market value } \\
\text { average Q4 2000) }\end{array}$ & $0.176^{*}$ & 0.79 & 0.115 & 0.008 & 0.125 & 1.000 & & & & & & & & \\
\hline $\begin{array}{l}\text { Ln (market value } \\
\text { average 2000) }\end{array}$ & $0.241 * *$ & 0.120 & $0.279 * *$ & -0.037 & $0.170^{*}$ & $0.929 * *$ & 1.000 & & & & & & & \\
\hline \multicolumn{15}{|l|}{ Control Var. } \\
\hline Competition & $-0.476^{* *}$ & $-0.198 * *$ & $-0.151^{*}$ & 0.025 & $-0.148^{+}$ & $-0.148^{+}$ & $-0.189^{*}$ & 1.000 & & & & & & \\
\hline Ln [market size] & -0.065 & -0.004 & $-0.260 * *$ & 0.094 & -0.052 & $0.217 * *$ & 0.105 & $0.179^{*}$ & 1.000 & & & & & \\
\hline Age of firm & $-0.135^{\dagger}$ & -0.101 & $-0.295 * *$ & 0.072 & -0.026 & $0.219 * *$ & 0.044 & 0.071 & $0.191 *$ & 1.000 & & & & \\
\hline Ln [employees] & 0.067 & -0.027 & $-0.164 *$ & 0.11 & -0.016 & $0.632 * *$ & $0.547 * *$ & 0.012 & $0.339 * *$ & $0.459 * *$ & 1.000 & & & \\
\hline Entry Mode & 0.069 & -0.037 & $0.443^{* *}$ & -0.068 & 0.075 & $-0.163 *$ & 0.014 & 0.007 & $-0.222 * *$ & $-0.488 * *$ & $-0.301 * *$ & 1.000 & & \\
\hline Product Scope & -0.060 & -0.016 & 0.009 & 0.054 & 0.092 & -0.093 & $-0.144^{\dagger}$ & 0.073 & -0.076 & 0.106 & $-0.140^{\dagger}$ & $-0.134^{+}$ & 1.000 & \\
\hline Market Scope & $0.155^{*}$ & 0.107 & $-0.131^{\dagger}$ & $-0.153^{*}$ & -0.060 & -0.012 & -0.026 & $-0.136^{\dagger}$ & 0.045 & 0.031 & -0.035 & $-0.145^{\dagger}$ & 0.100 & 1.000 \\
\hline \multicolumn{15}{|l|}{ Descriptive Stat. } \\
\hline Mean & 0.382 & 0.742 & 3.598 & 2.657 & 2.147 & 517 & 883 & 0.624 & 22410 & 7.0 & 1145 & 3.971 & 3.765 & 1.871 \\
\hline Median & 0.372 & 0.750 & 3.667 & 2.500 & 1 & 77 & 183 & 0.639 & 5400 & 4.3 & 270 & 4 & 4 & 1 \\
\hline Std. Deviation & 0.138 & 0.124 & 0.796 & 1.028 & 1.590 & 1491 & 2262 & 0.175 & 69111 & 7.9 & 3749 & 1.275 & 1.011 & 1.047 \\
\hline Min & 0.077 & 0.386 & 1.667 & 1 & 1 & 2 & 5 & 0 & 120 & 0.4 & 17 & 1 & 1 & 1 \\
\hline Max & 0.814 & 1 & 5 & 5 & 5 & 12304 & 16651 & 0.972 & 744000 & 46 & 31000 & 5 & 5 & 5 \\
\hline $\mathrm{N}$ & 170 & 170 & 170 & 170 & 170 & 161 & 169 & 170 & 170 & 170 & 170 & 170 & 170 & 170 \\
\hline \multicolumn{15}{|c|}{$\begin{array}{l}\text { Note on descriptive statistics: (1) The independent variables are indices that have been coded such that low values represent a low } \\
\text { emphasis, and high values represent a high emphasis on the respective business model design theme, or product market strategy. High } \\
\text { values of Entry Timing indicate early market entry timing. (2) Market value and market size are given in } \$ \text { millions, without taking the } \\
\text { logarithm. (3) Firm size is given as number of employees, without taking the logarithm. (3) High values of Entry Mode indicate high } \\
\text { reliance on strategic partnerships and/or joint ventures in developing, producing, or marketing products. (4) High values of Product } \\
\text { Scope indicate a highly focused product offering. (5) High values of Market Scope indicate a very focused market approach. }\end{array}$} \\
\hline$* * \mathrm{p}<0.01, * 0.01$ & $<=p<0.05$ & $5,^{\dagger} 0.05<$ & $<=\mathrm{p}<0.1$ & & & & & & & & & & & \\
\hline
\end{tabular}


TABLE 3: Pairwise Confirmatory Factor Analysis

\begin{tabular}{|c|c|c|c|c|c|c|c|c|c|c|c|c|}
\hline & \multicolumn{4}{|c|}{ Low Cost Strategy } & \multicolumn{4}{|c|}{ Differentiation } & \multicolumn{4}{|c|}{ Efficiency } \\
\hline & $\begin{array}{l}\text { Corre- } \\
\text { lation }\end{array}$ & $\begin{array}{c}\text { Chi- } \\
\text { squared }\end{array}$ & $\mathrm{DF}$ & $\begin{array}{c}\mathrm{P}- \\
\text { value }\end{array}$ & $\begin{array}{l}\text { Corre- } \\
\text { lation }\end{array}$ & $\begin{array}{c}\text { Chi- } \\
\text { squared }\end{array}$ & DF & $\begin{array}{c}\mathrm{P}- \\
\text { value }\end{array}$ & $\begin{array}{l}\text { Corre } \\
\text { lation }\end{array}$ & $\begin{array}{c}\text { Chi- } \\
\text { squared }\end{array}$ & $\mathrm{DF}$ & $\begin{array}{l}\mathrm{P}- \\
\text { value }\end{array}$ \\
\hline \multirow{3}{*}{$\begin{array}{l}\text { Differen- } \\
\text { tiation }\end{array}$} & $-0,07$ & 7,34 & 8 & 0,5007 & & & & & & & & \\
\hline & 0 & 7,86 & 9 & 0,5488 & & & & & & & & \\
\hline & 1 & 88,44 & 9 & 0 & & & & & & & & \\
\hline \multirow[t]{3}{*}{ Efficiency } & 0,01 & 164,03 & 103 & 0,0001 & 0,23 & 167,64 & 103 & 0 & & & & \\
\hline & 0 & 164,03 & 104 & 0,0002 & 0 & 171,84 & 104 & 0 & & & & \\
\hline & 1 & 443,12 & 104 & 0 & 1 & 246,55 & 104 & 0 & & & & \\
\hline \multirow[t]{3}{*}{ Novelty } & 0,05 & 165,28 & 103 & 0,0001 & 0,19 & 186,26 & 103 & 0 & 0,22 & 506,30 & 298 & 0 \\
\hline & 0 & 165,48 & 104 & 0,0001 & 0 & 189,12 & 104 & 0 & 0 & 507,11 & 299 & 0 \\
\hline & 1 & 550,21 & 104 & 0 & 1 & 260,00 & 104 & 0 & 1 & 735,09 & 299 & 0 \\
\hline
\end{tabular}

TABLE 4: Partial Least Squares Analysis

\begin{tabular}{|l|c|c|c|c|}
\hline & Differentiation & Cost Leadership & Efficiency & Novelty \\
\hline Differentiation & $\mathbf{0 , 5 7 7}$ & $-0,070$ & 0,060 & 0,148 \\
\hline CostLeadership & $-0,070$ & $\mathbf{0 , 5 7 7}$ & $-0,068$ & $-0,004$ \\
\hline Efficiency & 0,060 & $-0,068$ & $\mathbf{0 , 2 7 7}$ & 0,189 \\
\hline Novelty & 0,148 & $-0,004$ & 0,189 & $\mathbf{0 , 2 7 7}$ \\
\hline
\end{tabular}

Note: Table depicts square root of Average Variance Extracted on diagonal, and correlations on offdiagonal. 
TABLE 5: Selected Hierarchical OLS Regressions (Testing Hypothesis 1)

TABLE 5, Panel A: Mean Centered OLS Regression Results for Novelty-Differentiation Interaction

\begin{tabular}{|c|c|c|c|c|}
\hline \multirow[b]{2}{*}{ RHS Variables } & \multicolumn{4}{|c|}{ Dependent variable Ln (Market Value Avg. Quarter 4 2000) } \\
\hline & Model 1 & Model 2 & Model 3 & Model 4 \\
\hline & $\begin{array}{l}\text { Estimate (std. } \\
\text { error) }\end{array}$ & $\begin{array}{l}\text { Estimate (std. } \\
\text { error) }\end{array}$ & $\begin{array}{l}\text { Estimate (std. } \\
\text { error) }\end{array}$ & $\begin{array}{l}\text { Estimate (std. } \\
\text { error) }\end{array}$ \\
\hline Constant & $4.46 * * *$ & $4.54 * * *$ & -0.54 & -0.19 \\
\hline Novelty & $1.65^{\dagger}(1.20)$ & $1.45(1.14)$ & $1.45^{\dagger}(0.91)$ & $1.26^{\dagger}(0.93)$ \\
\hline Differentiation & $0.75(0.72)$ & $0.56(0.71)$ & $1.73 * * *(0.5)$ & $1.80 * * *(0.50)$ \\
\hline Novelty $*$ Differentiation & $14.66^{*}$ & $21.06 * *(7.00)$ & $8.93 *(5.15)$ & $11.07 *(5.05)$ \\
\hline$(\text { Novelty } * \text { Differentiation })^{\wedge} 2$ & . & $-186.28(108.65)$ & $-147.91(80.20)$ & $-158.92(74.98)$ \\
\hline Competition & . & \begin{tabular}{|l|l|}
. & \\
\end{tabular} & -0.65 & -0.48 \\
\hline Log (market size) & . & . & 0.078 & 0.071 \\
\hline Age & . & . & -0.01 & -0.014 \\
\hline Log (employees) & . & . & $0.86^{* * *}$ & $0.85 * * *$ \\
\hline Efficiency & & & & 0.95 \\
\hline Cost Leadership & . & . & . & -0.44 \\
\hline Timing of Entry & . & . & . & 0.16 \\
\hline Mode of Entry & . & . & . & -0.36 \\
\hline Product Scope & . & . & . & -0.02 \\
\hline Market Scope &. &. & . & -0.12 \\
\hline R-squared & 0.08 & 0.09 & 0.51 & 0.52 \\
\hline Adjusted R-squared & 0.06 & 0.07 & 0.48 & 0.47 \\
\hline $\mathrm{N}$ & 161 & 161 & 161 & 161 \\
\hline \multirow[t]{2}{*}{$\mathrm{F}$} & $4.35 * * *$ & $4.02 * *$ & $19.48 * * *$ & $11.18 * * *$ \\
\hline & \multicolumn{4}{|c|}{ Dependent variable Ln (Market Value Avg. 2000) } \\
\hline RHS Variables & Model 1 & Model 2 & Model 3 & Model 4 \\
\hline & Estimate & Estimate & Estimate & Estimate \\
\hline Constant & $5.38 * * *$ & $5.43 * * *$ & $1.31 *$ & $1.31^{\dagger}$ \\
\hline Novelty & $1.99 *(0.99)$ & $1.88 *(0.96)$ & $1.85 * *(0.77)$ & $1.57 *(0.79)$ \\
\hline Differentiation & $1.91 * * *(0.61)$ & $1.82 * *(0.61)$ & $2.58 * * *(0.43)$ & $2.40 * * *(0.42)$ \\
\hline (Novelty $*$ Differentiation) & $7.53^{\dagger}(5.23)$ & $11.46 *(5.86)$ & $2.01(4.23)$ & $3.72(3.99)$ \\
\hline$(\text { Novelty } * \text { Differentiation })^{\wedge} 2$ & . & $-111.14(83.37)$ & $-65.61(64.07)$ & $-79.36(54)$ \\
\hline Competition & . & . & -0.44 & -0.31 \\
\hline Log (market size) & . & . & 0.002 & 0.001 \\
\hline Age & . & . & -0.03 & -0.03 \\
\hline Log (employees) & . & . & $0.81 * * *$ & $0.80 * * *$ \\
\hline Efficiency & & & & $0.99^{\dagger}$ \\
\hline Cost Leadership & . & . & . & -0.51 \\
\hline Timing of Entry & . & . & . & 0.25 \\
\hline Mode of Entry & . & . & . & 0.10 \\
\hline Product Scope & . & . & & -0.21 \\
\hline Market Scope &. &. &. & -0.02 \\
\hline R-squared & 0.13 & 0.14 & 0.53 & 0.54 \\
\hline Adjusted R-squared & 0.11 & 0.12 & 0.50 & 0.50 \\
\hline $\mathrm{N}$ & 169 & 169 & 169 & 169 \\
\hline $\mathrm{F}$ & $8.24 * * *$ & $6.56 * * *$ & $22.19 * * *$ & $13.02 * * *$ \\
\hline
\end{tabular}

$* * * \mathrm{p}<0.001, * * \mathrm{p}<0.01, * 0.01<=\mathrm{p}<0.05,{ }^{\dagger} 0.05<=\mathrm{p}<0.1$ 
FIGURE 1: $\quad$ Plot Of Differentiation On Performance For Different Values Of Novelty (Mean Value, $\mathrm{N}_{\mathrm{m}}$, One Standard Deviation Below The Mean, $\mathrm{N}_{\mathrm{l}}$, One Standard Deviation Above The Mean, $\mathrm{N}_{\mathrm{h}}$ )

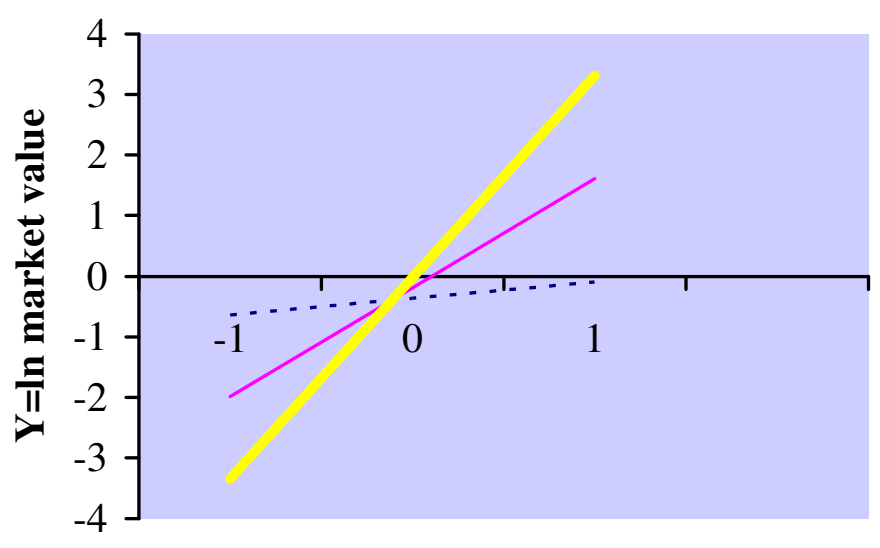

Differentiation Strategy

$\cdots+\mathrm{Nl}-\mathrm{Nm}$

FIGURE 2: $\quad$ Plot Of Novelty On Performance For Different Values Of Differentiation (Mean Value, $\mathrm{D}_{\mathrm{m}}$, One Standard Deviation Below The Mean, $\mathrm{D}_{\mathrm{l}}$, One Standard Deviation Above The Mean, $\mathrm{D}_{\mathrm{h}}$ )

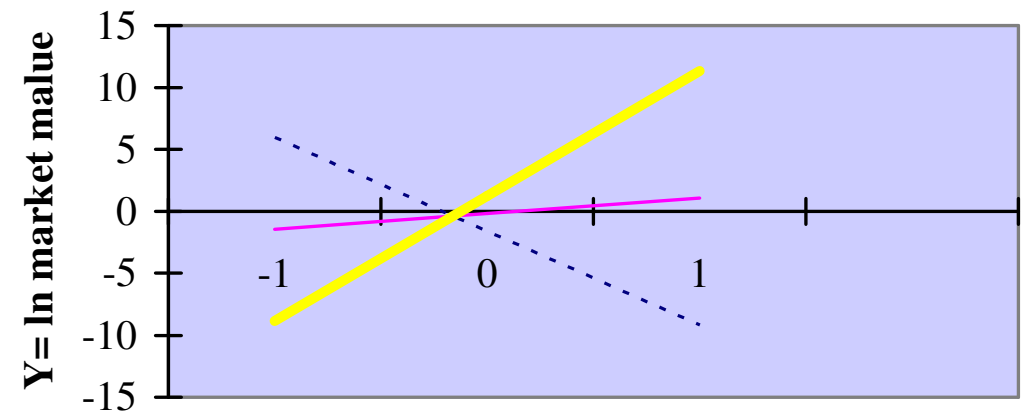

Novelty-centered Business Model Design

$$
\cdots \cdot \mathrm{Dl}-\mathrm{Dm}
$$




\section{Appendix: Scale Composition}

\begin{tabular}{|c|c|c|c|c|c|c|}
\hline $\begin{array}{c}\text { Items Composing Efficiency- } \\
\text { Centered Business Model } \\
\text { Design Theme Scale }\end{array}$ & Scale (Code) & $\begin{array}{l}\text { Retained } \\
\text { in final } \\
\text { scale }\end{array}$ & Mean & STD & Min & Max \\
\hline $\begin{array}{l}\text { Inventory costs for participants } \\
\text { in the business model are } \\
\text { reduced }\end{array}$ & $\begin{array}{l}\text { Strongly Agree (1), Agree } \\
(0.75) \text {, Disagree }(0.25), \text { Strongly } \\
\text { Disagree }(0)\end{array}$ & $\checkmark$ & 0.79 & 0.25 & 0 & 1 \\
\hline $\begin{array}{l}\text { Transactions are simple from } \\
\text { the user's point of view }\end{array}$ & $\begin{array}{l}\text { Strongly Agree (1), Agree } \\
(0.75) \text {, Disagree }(0.25), \text { Strongly } \\
\text { Disagree }(0)\end{array}$ & $\checkmark$ & 0.80 & 0.23 & 0 & 1 \\
\hline $\begin{array}{l}\text { The business model enables a } \\
\text { low number of errors in the } \\
\text { execution of transactions }\end{array}$ & $\begin{array}{l}\text { Strongly Agree (1), Agree } \\
(0.75) \text {, Disagree }(0.25), \text { Strongly } \\
\text { Disagree }(0)\end{array}$ & $\checkmark$ & 0.68 & 0.25 & 0 & 1 \\
\hline $\begin{array}{l}\text { Costs other than those already } \\
\text { mentioned for participants in } \\
\text { the business model are reduced } \\
\text { (e.g., marketing \& sales, } \\
\text { transaction processing, } \\
\text { communication costs) }\end{array}$ & $\begin{array}{l}\text { Strongly Agree (1), Agree } \\
(0.75) \text {, Disagree (0.25), Strongly } \\
\text { Disagree (0) }\end{array}$ & $\checkmark$ & 0.51 & 0.34 & 0 & 1 \\
\hline $\begin{array}{l}\text { The business model is scalable } \\
\text { (i.e., can handle small as well as } \\
\text { large number of transactions) }\end{array}$ & $\begin{array}{l}\text { Strongly Agree (1), Agree } \\
(0.75), \text { Disagree }(0.25), \\
\text { Strongly Disagree }(0)\end{array}$ & $\checkmark$ & 0.80 & 0.22 & 0 & 1 \\
\hline $\begin{array}{l}\text { The business model enables } \\
\text { participants to make informed } \\
\text { decisions }\end{array}$ & $\begin{array}{l}\text { Strongly Agree (1), Agree } \\
(0.75) \text {, Disagree }(0.25), \text { Strongly } \\
\text { Disagree }(0)\end{array}$ & $\checkmark$ & 0.82 & 0.18 & 0.25 & 1 \\
\hline $\begin{array}{l}\text { Transactions are transparent: } \\
\text { flows and use of information, } \\
\text { services, goods can be verified }\end{array}$ & $\begin{array}{l}\text { Strongly Agree (1), Agree } \\
(0.75) \text {, Disagree }(0.25), \text { Strongly } \\
\text { Disagree }(0)\end{array}$ & $\checkmark$ & 0.78 & 0.24 & 0 & 1 \\
\hline $\begin{array}{l}\text { As part of transactions, } \\
\text { information is provided to } \\
\text { participants to reduce } \\
\text { asymmetric degree of } \\
\text { knowledge amongst them } \\
\text { regarding the quality and nature } \\
\text { of the goods being exchanged }\end{array}$ & $\begin{array}{l}\text { Strongly Agree (1), Agree } \\
(0.75) \text {, Disagree }(0.25), \text { Strongly } \\
\text { Disagree (0) }\end{array}$ & $\checkmark$ & 0.71 & 0.27 & 0 & 1 \\
\hline $\begin{array}{l}\text { As part of transactions, } \\
\text { information is provided to } \\
\text { participants about each other }\end{array}$ & $\begin{array}{l}\text { Strongly Agree (1), Agree } \\
(0.75) \text {, Disagree }(0.25), \text { Strongly } \\
\text { Disagree }(0)\end{array}$ & $\checkmark$ & 0.66 & 0.28 & 0 & 1 \\
\hline $\begin{array}{l}\text { Access to large range of } \\
\text { products, services and } \\
\text { information, and other } \\
\text { participants is provided }\end{array}$ & $\begin{array}{l}\text { Strongly Agree (1), Agree } \\
(0.75), \text { Disagree }(0.25), \text { Strongly } \\
\text { Disagree (0) }\end{array}$ & & 0.85 & 0.23 & 0 & 1 \\
\hline $\begin{array}{l}\text { The business model enables } \\
\text { demand aggregation }\end{array}$ & Yes (1), No (0); & & 0.12 & 0.32 & 0 & 1 \\
\hline $\begin{array}{l}\text { The business model enables fast } \\
\text { transactions }\end{array}$ & $\begin{array}{l}\text { Strongly Agree (1), Agree } \\
(0.75), \text { Disagree }(0.25), \text { Strongly } \\
\text { Disagree }(0)\end{array}$ & $\checkmark$ & 0.81 & 0.25 & 0 & 1 \\
\hline $\begin{array}{l}\text { The business model, overall, } \\
\text { offers high transaction } \\
\text { efficiency }\end{array}$ & $\begin{array}{l}\text { Strongly Agree (1), Agree } \\
(0.75), \text { Disagree }(0.25), \text { Strongly } \\
\text { Disagree }(0)\end{array}$ & $\checkmark$ & 0.79 & 0.22 & 0 & 1 \\
\hline Reliability $\alpha$ & 0.70 & & & & & \\
\hline
\end{tabular}


Appendix: Scale Composition (cont'd)

\begin{tabular}{|c|c|c|c|c|c|c|}
\hline $\begin{array}{c}\text { Items Composing } \\
\text { Novelty-Centered } \\
\text { Business Model Design } \\
\text { Theme Scale }\end{array}$ & Scale (Code) & $\begin{array}{l}\text { Retained in } \\
\text { final scale }\end{array}$ & Mean & STD & Min & $\operatorname{Max}$ \\
\hline $\begin{array}{l}\text { The business model offers } \\
\text { new combinations of } \\
\text { products, services and } \\
\text { information }\end{array}$ & $\begin{array}{l}\text { Strongly Agree (coded as } 1), \\
\text { Agree (0.75), Disagree (0.25), } \\
\text { Strongly Disagree (0) }\end{array}$ & $\checkmark$ & 0.42 & 0.30 & 0 & 1 \\
\hline $\begin{array}{l}\text { The business model brings } \\
\text { together new participants }\end{array}$ & $\begin{array}{l}\text { Strongly Agree (coded as } 1), \\
\text { Agree }(0.75) \text {, Disagree }(0.25) \text {, } \\
\text { Strongly Disagree }(0)\end{array}$ & $\checkmark$ & 0.27 & 0.22 & 0 & 1 \\
\hline $\begin{array}{l}\text { Incentives offered to } \\
\text { participants in transactions } \\
\text { are novel }\end{array}$ & $\begin{array}{l}\text { Strongly Agree (coded as } 1), \\
\text { Agree }(0.75), \text { Disagree }(0.25) \text {, } \\
\text { Strongly Disagree }(0)\end{array}$ & $\checkmark$ & 0.32 & 0.25 & 0 & 1 \\
\hline $\begin{array}{l}\text { The business model gives } \\
\text { access to an unprecedented } \\
\text { variety and number of } \\
\text { participants and/or goods }\end{array}$ & $\begin{array}{l}\text { Strongly Agree (coded as } 1) \text {, } \\
\text { Agree }(0.75), \text { Disagree }(0.25) \text {, } \\
\text { Strongly Disagree }(0)\end{array}$ & $\checkmark$ & 0.39 & 0.30 & 0 & 1 \\
\hline $\begin{array}{l}\text { The business model links } \\
\text { participants to transactions } \\
\text { in novel ways }\end{array}$ & $\begin{array}{l}\text { Strongly Agree (coded as } 1) \text {, } \\
\text { Agree }(0.75) \text {, Disagree }(0.25) \text {, } \\
\text { Strongly Disagree }(0)\end{array}$ & $\checkmark$ & 0.32 & 0.24 & 0 & 1 \\
\hline $\begin{array}{l}\text { The richness (i.e., quality } \\
\text { and depth) of some of the } \\
\text { links between participants } \\
\text { is novel }\end{array}$ & $\begin{array}{l}\text { Strongly Agree (coded as } 1) \text {, } \\
\text { Agree }(0.75) \text {, Disagree }(0.25) \text {, } \\
\text { Strongly Disagree (0) }\end{array}$ & $\checkmark$ & 0.36 & 0.27 & 0 & 1 \\
\hline $\begin{array}{l}\text { Number of patents that the } \\
\text { focal firm has been } \\
\text { awarded for aspects of its } \\
\text { business model }\end{array}$ & $\begin{array}{l}0(0), 1-2(0.33), 3-4(0.66),>4 \\
(1)\end{array}$ & $\checkmark$ & 0.054 & 0.19 & 0 & 1 \\
\hline $\begin{array}{l}\text { Extent to which the } \\
\text { business model relies on } \\
\text { trade secrets and/or } \\
\text { copyrights }\end{array}$ & $\begin{array}{l}\text { Radically (1), Substantially } \\
(0.66), \text { A bit }(0.33), \text { Not at all } \\
(0)\end{array}$ & $\checkmark$ & 0.52 & 0.28 & 0 & 1 \\
\hline $\begin{array}{l}\text { Does the focal firm claim } \\
\text { to be a pioneer with its } \\
\text { business model? }\end{array}$ & Yes (1), No (0); & $\checkmark$ & 0.4 & 0.49 & 0 & 1 \\
\hline $\begin{array}{l}\text { The focal firm has } \\
\text { continuously introduced } \\
\text { innovations in its business } \\
\text { model }\end{array}$ & $\begin{array}{l}\text { Strongly Agree (coded as } 1), \\
\text { Agree (0.75), Disagree (0.25), } \\
\text { Strongly Disagree (0) }\end{array}$ & $\checkmark$ & 0.6 & 0.33 & 0 & 1 \\
\hline $\begin{array}{l}\text { There are competing } \\
\text { business models with the } \\
\text { potential to leapfrog the } \\
\text { firm's business model }\end{array}$ & $\begin{array}{l}\text { Strongly Agree (coded as } 1), \\
\text { Agree (0.75), Disagree (0.25), } \\
\text { Strongly Disagree (0) }\end{array}$ & $\checkmark$ & 0.47 & 0.30 & 0 & 1 \\
\hline $\begin{array}{l}\text { There are other important } \\
\text { aspects of the business } \\
\text { model that make it novel }\end{array}$ & $\begin{array}{l}\text { Strongly Agree (coded as } 1) \text {, } \\
\text { Agree }(0.75) \text {, Disagree }(0.25) \text {, } \\
\text { Strongly Disagree }(0)\end{array}$ & $\checkmark$ & 0.30 & 0.27 & 0 & 1 \\
\hline $\begin{array}{l}\text { Overall, the company's } \\
\text { business model is novel }\end{array}$ & $\begin{array}{l}\text { Strongly Agree (coded as } 1), \\
\text { Agree }(0.75), \text { Disagree }(0.25) \text {, } \\
\text { Strongly Disaggee }(0)\end{array}$ & $\checkmark$ & 0.53 & 0.31 & 0 & 1 \\
\hline Reliability $\alpha$ & 0.71 & & & & & \\
\hline
\end{tabular}


Appendix: Scale Composition (cont'd)

\begin{tabular}{|c|c|c|c|c|c|c|}
\hline $\begin{array}{c}\text { Items Composing } \\
\text { Differentiation Strategy } \\
\text { Scale }\end{array}$ & Scale & $\begin{array}{l}\text { Retained in } \\
\text { final scale }\end{array}$ & Mean & STD & Min & Max \\
\hline $\begin{array}{l}\text { Importance and use of } \\
\text { product-service-related } \\
\text { patents, }\end{array}$ & $\begin{array}{l}\text { SCALE: } 1=\text { not important at all, } \\
2=\text { slightly important, } 3= \\
\text { moderately important, } 4= \\
\text { important, } 5=\text { very important }\end{array}$ & $\checkmark$ & 3.05 & 1.30 & 1 & 5 \\
\hline $\begin{array}{l}\text { Importance of new product } \\
\text { development, innovation } \\
\text { and R\&D activity }\end{array}$ & $\begin{array}{l}\text { SCALE: } 1=\text { not important at all, } \\
2=\text { slightly important, } 3= \\
\text { moderately important, } 4= \\
\text { important, } 5=\text { very important }\end{array}$ & & 4.24 & 1.01 & 1 & 5 \\
\hline $\begin{array}{l}\text { Emphasis on growth by } \\
\text { acquiring, or merging with } \\
\text { R\&D / technology } \\
\text { intensive firms, firms } \\
\end{array}$ & $\begin{array}{l}\text { SCALE: } 1=\text { not important at all, } \\
2=\text { slightly important, } 3= \\
\text { moderately important, } 4= \\
\text { important, } 5=\text { very important }\end{array}$ & & 3.45 & 1.30 & 1 & 5 \\
\hline $\begin{array}{l}\text { Branding and advertising } \\
\text { as part of firm's marketing } \\
\text { strategy / approach }\end{array}$ & $\begin{array}{l}\text { SCALE: } 1=\text { not important at all, } \\
2=\text { slightly important, } 3= \\
\text { moderately important, } 4= \\
\text { important, } 5=\text { very important }\end{array}$ & $\checkmark$ & 4.15 & 1.23 & 1 & 5 \\
\hline Differentiation strategy & $\begin{array}{l}\text { SCALE: } 1=\text { do not use this } \\
\text { strategy at all, } 2=\text { strategy is not } \\
\text { important, } 3=\text { use this strategy a } \\
\text { bit, } 4=\text { employ this strategy, } 5= \\
\text { very important strategy }\end{array}$ & $\checkmark$ & 3.59 & 0.55 & 1 & 5 \\
\hline Reliability $\alpha$ & 0.66 & & & & & \\
\hline
\end{tabular}

\begin{tabular}{|c|c|c|c|c|c|c|}
\hline $\begin{array}{l}\text { Items Composing Cost } \\
\text { Leadership Strategy } \\
\text { Scale }\end{array}$ & Scale & $\begin{array}{l}\text { Retained in } \\
\text { final scale }\end{array}$ & Mean & STD & Min & Max \\
\hline $\begin{array}{l}\text { Offering products / services } \\
\text { at low prices / prices lower } \\
\text { than competition }\end{array}$ & $\begin{array}{l}\text { SCALE: } 1=\text { not important at all, } \\
2=\text { slightly important, } 3= \\
\text { moderately important, } 4= \\
\text { important, } 5=\text { very important }\end{array}$ & $\checkmark$ & 3.18 & 1.55 & 1 & 5 \\
\hline $\begin{array}{l}\text { Minimizing product-related } \\
\text { expenditures, in particular } \\
\text { through process } \\
\text { innovations }\end{array}$ & $\begin{array}{l}\text { SCALE: } 1=\text { not important at all, } \\
2=\text { slightly important, } 3= \\
\text { moderately important, } 4= \\
\text { important, } 5=\text { very important }\end{array}$ & $\checkmark$ & 2.79 & 1.57 & 1 & 5 \\
\hline $\begin{array}{l}\text { Emphasizing economies of } \\
\text { scale and scope with } \\
\text { products and services }\end{array}$ & $\begin{array}{l}\text { SCALE: } 1=\text { not important at all, } \\
2=\text { slightly important, } 3= \\
\text { moderately important, } 4= \\
\text { important, } 5=\text { very important }\end{array}$ & $\checkmark$ & 1.82 & 1.37 & 1 & 5 \\
\hline Low-cost strategy & $\begin{array}{l}\text { SCALE: } 1=\text { do not use this } \\
\text { strategy at all, } 2=\text { strategy is not } \\
\text { important, } 3=\text { use this strategy a } \\
\text { bit, } 4=\text { employ this strategy, } 5= \\
\text { very important strategy }\end{array}$ & $\checkmark$ & 2.84 & 1.02 & 1 & 5 \\
\hline Reliability $\alpha$ & 0.76 & & & & & \\
\hline
\end{tabular}


Appendix: Scale Composition (cont'd)

\begin{tabular}{|l|l|c|c|c|c|c|}
\hline $\begin{array}{l}\text { Items For Other Strategy } \\
\text { Variables }\end{array}$ & \multicolumn{1}{|c|}{ Scale } & $\begin{array}{l}\text { Retained in } \\
\text { final scale }\end{array}$ & Mean & STD & Min & Max \\
\hline $\begin{array}{l}\text { Timing of market entry } \\
\text { (Being the first to enter a } \\
\text { market, and/or first to } \\
\text { introduce products / } \\
\text { services in a market, or } \\
\text { realizing first mover } \\
\text { advantage in another way) }\end{array}$ & $\begin{array}{l}\text { SCALE: 1 = not important at } \\
\text { all, 2 = slightly important, 3 } \\
\text { moderately important, } 4= \\
\text { important, 5 = very important }\end{array}$ & $\checkmark$ & 2.15 & 1.59 & 1 & 5 \\
\hline $\begin{array}{l}\text { Mode of market entry } \\
\text { (Relying on strategic } \\
\text { partnerships, and joint } \\
\text { ventures in order to } \\
\text { develop, produce, } \\
\text { distribute, or market } \\
\text { products / services) }\end{array}$ & $\begin{array}{l}\text { SCALE: 1 = not important at } \\
\text { all, 2= slightly important, 3 } \\
\text { moderately important, 4= } \\
\text { important, 5 = very important }\end{array}$ & $\checkmark$ & 3.97 & 1.27 & 1 & 5 \\
\hline $\begin{array}{l}\text { Breadth of product } \\
\text { offering (Pursuing a } \\
\text { narrow, focused product } \\
\text { scope) }\end{array}$ & $\begin{array}{l}\text { SCALE 1: 1 = not important at } \\
\text { all, 2= slightly important, 3 } \\
\text { moderately important, 4= } \\
\text { important, 5 = very important }\end{array}$ & $\checkmark$ & 3.76 & 1.01 & 1 & 5 \\
\hline $\begin{array}{l}\text { Breadth of targeted market } \\
\text { segments (Pursuing a } \\
\text { narrow, focused market } \\
\text { scope) }\end{array}$ & $\begin{array}{l}\text { SCALE: 1 = not important at } \\
\text { all, 2= slightly important, 3 } \\
\text { moderately important, } 4= \\
\text { important, 5 = very important }\end{array}$ & $\checkmark$ & 1.87 & 1.05 & 1 & 5 \\
\hline
\end{tabular}

